Article

\title{
Long-Term Effects of Animal Manures on Nutrient Recovery and Soil Quality in Acid Typic Hapludalf under No-Till Conditions
}

\author{
Paulo Ademar Avelar Ferreira ${ }^{1, *(\mathbb{D})}$, Carlos Alberto Ceretta ${ }^{2}$, Cledimar Rogério Lourenzi ${ }^{3}$ (D) , Lessandro De Conti ${ }^{4}$, \\ Carina Marchezan $^{2} \mathbb{D}$, Eduardo Girotto ${ }^{5}\left(\mathbb{D}\right.$, Tadeu Luis Tiecher ${ }^{6} \mathbb{D}$, Natália Moreira Palermo ${ }^{2}(\mathbb{D}$, \\ Léon-Étienne Parent ${ }^{7}$ (D) and Gustavo Brunetto ${ }^{2}$
}

Citation: Ferreira, P.A.A.; Ceretta, C.A.; Lourenzi, C.R.; De Conti, L.; Marchezan, C.; Girotto, E.; Tiecher, T.L.; Palermo, N.M.; Parent, L.-É.; Brunetto, G. Long-Term Effects of Animal Manures on Nutrient Recovery and Soil Quality in Acid Typic Hapludalf under No-Till Conditions. Agronomy 2022, 12, 243. https://doi.org/10.3390/ agronomy12020243

Academic Editor: Arno Rosemarin

Received: 11 December 2021

Accepted: 16 January 2022

Published: 19 January 2022

Publisher's Note: MDPI stays neutral with regard to jurisdictional claims in published maps and institutional affiliations.

Copyright: (C) 2022 by the authors. Licensee MDPI, Basel, Switzerland. This article is an open access article distributed under the terms and conditions of the Creative Commons Attribution (CC BY) license (https:// creativecommons.org/licenses/by/ $4.0 /)$.
1 Academic Coordination, Campus Cachoeira do Sul, Federal University of Santa Maria, Rodovia Taufik Germano, 3013, Bairro Passo D'Areia, Cachoeira do Sul Cep 96503-205, RS, Brazil

2 Department of Soil Science, Federal University of Santa Maria, Avenida Roraima, 1000, Bairro Camobi, Santa Maria Cep 97105-900, RS, Brazil; carlosceretta@gmail.com (C.A.C.); marchezancarina@gmail.com (C.M.); natimpalermo@gmail.com (N.M.P.); brunetto.gustavo@gmail.com (G.B.)

3 Department of Rural Engineering, Federal University of Santa Catarina, Rodovia Admar Gonzaga, 1346, Bairro Itacorubi, Florianópolis Cep 88034-000, SC, Brazil; lourenzi.c.r@ufsc.br

4 Farroupilha Federal Institute of Education, Science and Technology, Fábio João Andolhe Street, 1100, Bairro Floresta, Santo Augusto Cep 98590-000, RS, Brazil; lessandrodeconti@gmail.com

5 Federal Institute of Education, Science and Technology of Rio Grande do Sul, Campus Bento Gonçalves, Avenida Osvaldo Aranha, 540, Bairro Juventude da Enologia, Bento Gonçalves Cep 95700-206, RS, Brazil; eduardo.girotto@ifrs.edu.br

6 Federal Institute of Education, Science and Technology of Rio Grande do Sul, Campus Restinga, Alberto Hoffmann Street, 285, Bairro Restinga, Porto Alegre Cep 91791-508, RS, Brazil; tadeu.tiecher@restinga.ifrs.edu.br

7 Department of Soil and Agri-Food Engineering, Université Laval, Québec, QC G1V 0A6, Canada; Leon-Etienne.Parent@fsaa.ulaval.ca

* Correspondence: ferreira.aap@gmail.com

\begin{abstract}
No-till farming and manure application are means of storing carbon in soil and increasing soil quality. However, the organic fertilization of no-till soils may sustain subtropical agroecosystems for only a limited period until the soil quality declines. The C, N, P, and other nutrient cycles are perturbed due to the nutrient imbalance in manures and their application on the soil surface, which poses a risk for nutrient dispersion into the environment. Long-term N-based manure application also impacts the apparent nutrient recovery (ANR) by crops and, hence, the crop quality. Our objective was to monitor changes in soil quality and to measure nutrient recovery from $\mathrm{N}$-based organic fertilization in a Brazilian agroecosystem. A long-term experiment was established in May 2004 on Typic Hapludalf soil in Southern Brazil. The experiment comprised two periods: 2004-2009 and 2009-2020. The treatments were unfertilized (control), pig slurry, pig deep litter (swine manure and rice husk), cattle slurry, and mineral fertilizer (urea, triple superphosphate, and $\mathrm{K}$ chloride). Grain and cover crops were grown. The maize grain yield and oat biomass were used as indicators of productivity. The application of cattle slurry, pig deep litter, and pig slurry increased the grain production by $20 \%$ on average compared to mineral fertilization. Organic manuring increased the soil $\mathrm{pH}$ by up to one unit, while urea acidified the soil. The highest crop yields were obtained with pig deep litter, which increased the levels of $\mathrm{P}, \mathrm{K}, \mathrm{Ca}, \mathrm{Mg}$, and $\mathrm{C}$ in the soil test. Pig deep litter showed the highest N-ANR for the aboveground part of the plants. The ANRs for $\mathrm{P}, \mathrm{K}, \mathrm{Ca}$, and $\mathrm{Mg}$ were also highest when pig slurry had been applied. The ANR values for the micronutrients varied widely among the organic sources but indicated large marginal offtake gains compared to mineral fertilization. The N-based fertilization with animal manures increased the rate of nutrient uptake by plants but led to an accumulation of nutrients in the soil, threatening the sustainability of the system. Manure applications must be monitored regularly to avoid the accumulation of nutrients that could impair the soil quality and become an environmental problem in the future.
\end{abstract}


Keywords: organic waste; soil nutrient; crop yield; long-term experiments; machine-learning methods

\section{Introduction}

The recycling of organic waste is a potential solution to promote a circular economy [1]. In agriculture, the objective of the bioeconomy is to reduce inorganic fertilization by using animal manures, slurries, or crop residues [2,3]. However, this poses a serious long-term threat to soil quality due to the mismatch between the composition of organic amendments, the nutrient recovery of crops, and their capacity to retain and recycle macroand micronutrients.

Carbon can be stored in soils using conservation tillage (no-till or minimum-tillage systems) in combination with primary production (crop residues, intercropping, cover crops, agroforestry, and crop rotations), irrigation, nitrogen fertilization, and organic amendments [4]. Although appealing, carbon storage practices possess their own contradictions. No-till practices leave manure on the soil surface, facilitating phosphorus dispersion through runoff [5]. Manure has imbalanced C:N [6] and N:P ratios [7]. Hence, increasing C storage with manure may cause excessive $\mathrm{P}$ accumulation in the soil, which is a serious environmental risk [8]. The application of organic residues increases microbial activity; soil $\mathrm{pH}$; soil test levels of $\mathrm{P}, \mathrm{K}, \mathrm{Ca}, \mathrm{Mg}, \mathrm{Zn}$, and $\mathrm{Cu} ; \mathrm{C}$ content; water retention; the aggregation of soil; and carbon sequestration [9,10]. Animal manures impact the nutrient recovery of crops due to their more variable compositions and differential reaction rates compared to mineral fertilizers [11-14]. Nutrient recovery depends on a soil's capacity to supply nutrients and a plant's ability to acquire, transport, and remobilize nutrients [15]. Where soils show a multielemental deficiency, organic waste can increase crop yields more than synthetic fertilizer [16]. Cropping systems, including crop residue management and cover crops, contribute to enhanced nutrient recovery [17].

The Southern Brazilian states account for $12 \%$ of the national cattle breeding and $49 \%$ of the swine production $[18,19]$. The phenomenal amounts of animal manure generated by these activities require wise nutrient management to maintain soil productivity while minimizing environmental impacts and loss of soil quality in the long run, especially in notill soils $[20,21]$. Animal manures are typically recycled near their production sites for crop fertilization, potentially increasing soil nutrient levels $[13,22-25]$ and reducing expenses due to commercial fertilizers that small farmers may not be able to afford [12,14,26,27]. The N-based application of animal manures has led to the excessive soil accumulation of $\mathrm{P}, \mathrm{Cu}$, and $\mathrm{Zn}[21,28]$ and has contributed to the eutrophication of surface waters [29]. Long-term experiments can assess a system's sustainability by monitoring the effects of fertilizer treatments on yield stability, nutrient management, soil chemical quality [30-33], and long-lasting carryover effects [34].

We hypothesized that (1) the soil test levels of nutrients and $\mathrm{C}$ are proportional to the elemental budgets for the N-based fertilizer additions and (2) the apparent nutrient recovery rates for the $\mathrm{N}$-based organic fertilizers are equal but higher than for mineral fertilization. Our objectives were to monitor changes in soil chemical quality and to measure nutrient recovery from $\mathrm{N}$-based organic fertilization in a Brazilian agroecosystem.

\section{Materials and Methods}

\subsection{Experimental Setup}

A long-term experiment was established in May 2004 on a Typic Hapludalf (red-yellow podzolic) soil [35] at the Federal University of Santa Maria (UFSM) research farm in the Central Depression of the Rio Grande do Sul, Brazil $\left(29^{\circ} 41^{\prime} 25^{\prime \prime} \mathrm{S}\right.$ and $53^{\circ} 48^{\prime} 42^{\prime \prime} \mathrm{W}$; altitude $=113 \mathrm{~m})$. Surface soil $(0-20 \mathrm{~cm})$ contained $180 \mathrm{~g}$ clay $\mathrm{kg}^{-1}, 193 \mathrm{~g}$ silt kg ${ }^{-1}$, and $627 \mathrm{~g}$ sand $\mathrm{kg}^{-1}$. The climate of the region is humid subtropical and of the type Cfa according to Köppen's classification. Average annual temperature is $19.3^{\circ} \mathrm{C}$, mean annual rainfall is $1561 \mathrm{~mm}$, and mean relative air humidity is $82 \%$. 
The experiment comprised two periods: 2004-2009 (establishment period) and 2009-2020. The crop sequences are presented in Table 1 for the entire experimental period. In the first period, the treatments were applied once a year before sowing maize (Zea mays L.). Maize was followed by black oat (Avena strigosa Schreb.) and radish (Raphanus sativus L.). Treatments starting in 2009 were applied twice a year, one preceding the winter crop and the other preceding the summer crop.

Table 1. Crop sequence throughout the long-term experiment.

\begin{tabular}{ccc}
\hline Year & Winter Crop & Summer Crop \\
\hline 2004 & Avena sativa & Zea mays \\
2005 & Raphanus sativus & Zea mays \\
2006 & Avena sativa & Zea mays \\
2007 & Raphanus sativus & Zea mays \\
2008 & Avena sativa & Zea mays \\
2009 & Raphanus sativus & Zea mays \\
2010 & Avena sativa & Zea mays \\
2011 & Avena sativa & Zea mays \\
2012 & Avena sativa & Phaseolus vulgaris \\
2013 & Avena sativa & Zea mays \\
2014 & Triticum aestivum mays \\
2015 & Avena sativa & Zea mays \\
2016 & Avena sativa & Zea mays \\
2017 & Avena sativa & Phaseolus vulgaris \\
2018 & Avena sativa & Zea mays \\
\end{tabular}

The tillage system was no-till [21]. The aboveground portion of oilseed radish and oat were left on the ground as green manure. Plants were desiccated at flowering. For other crops, grain was harvested and crop residues were left on the soil surface.

There were five fertilization treatments, as follows: unfertilized (control), pig slurry, pig deep litter (swine manure and rice husk), cattle slurry, and mineral fertilization (urea, triple superphosphate, and $\mathrm{K}$ chloride). The $\mathrm{C}: \mathrm{N}$ ratios of organic materials varied widely among sources, as follows: $9.01 \pm 6.75$ for cattle slurry (median value = 7.28), $23.91 \pm 14.09$ for pig deep litter (median value $=20.81$ ), and $3.21 \pm 1.078$ for pig slurry (median value $=3.14$ ). Total $\mathrm{N}$ was applied before sowing at rates of $30 \mathrm{~kg} \mathrm{~N} \mathrm{ha}^{-1}$ for oat (expected yield $=2000 \mathrm{~kg}_{\text {grain ha }}{ }^{-1}$ ), $105 \mathrm{~kg} \mathrm{~N} \mathrm{ha}^{-1}$ for maize (expected yield $=5000 \mathrm{~kg}_{\text {grain ha }}{ }^{-1}$ ), and $60 \mathrm{~kg} \mathrm{~N} \mathrm{ha}{ }^{-1}$ for bean $\left(\right.$ expected yield $=1500 \mathrm{~kg}$ grain ha $\left.{ }^{-1}\right)$. Before sowing, oat received $13 \mathrm{~kg} \mathrm{P} \mathrm{ha-1}$ and $17 \mathrm{~kg} \mathrm{~K} \mathrm{ha}^{-1}$, while maize received $26 \mathrm{~kg} \mathrm{P} \mathrm{ha}^{-1}$ and $58 \mathrm{~kg} \mathrm{~K} \mathrm{ha}^{-1}$ and bean received $11 \mathrm{~kg} \mathrm{P} \mathrm{ha}^{-1}$ and $25 \mathrm{~kg} \mathrm{~K}$ ha $^{-1}$. The amounts of C, N, P, K, Ca, Mg, Cu, and $\mathrm{Zn}$ applied during the 2004-2009, 2009-2012, 2012-2016, and 2016-2020 periods are shown in Supplementary Table S1. Treatments were arranged as a randomized block design with four replications. Plot size was $5 \mathrm{~m}$ by $5 \mathrm{~m}$.

The dosage of solid organic waste was computed as follows, CQFS RS/SC [36] (Equation (1)):

$$
A=\frac{Q}{(B / 100) \times(C / 100) \times D}
$$

where $A$ is dosage of the organic waste in $\mathrm{kg} \mathrm{ha}^{-1}, Q$ is recommended amount of available elements in $\mathrm{kg} \mathrm{ha}^{-1}, B$ is concentration of dry matter in the organic waste, $C$ is elemental concentration in \% in the dry matter in the organic waste, and $D$ is agronomic efficiency of the element (fertilizer coefficient efficiency for providing nutrient to the first crop after manure application). For solid swine manure, $D$ was 0.6 for $\mathrm{N}, 0.8$ for $\mathrm{P}$, and 1.0 for $\mathrm{K}$ for the first crop; and 0.2 for $\mathrm{N}$ and $\mathrm{P}$ for the following crop. 
The dosage of slurries was computed as follows (Equation (2)):

$$
A=\frac{Q}{C \times D}
$$

where $A$ and $Q$ are as above and $C$ is elemental concentration in the slurry, expressed in $\mathrm{kg} \mathrm{m}^{-3}$. For cattle slurry, $D$ was 0.5 for $\mathrm{N}, 0.8$ for $\mathrm{P}$, and 1.0 for $\mathrm{K}$ for the first crop; and 0.2 for $\mathrm{N}$ and $\mathrm{P}$ for the following crop. For swine slurry, $D$ was 0.8 for $\mathrm{N}, 0.9$ for $\mathrm{P}$, and 1.0 for $\mathrm{K}$ for the first crop; and 0.1 for $\mathrm{P}$ for the following crop.

\subsection{Soil Analyses}

Soils were sampled in the 0-10 and 10-20 cm layers in 2004, 2008, 2012, 2016, and 2020, air dried, and sieved to less than $2 \mathrm{~mm}$. Soil $\mathrm{pH}$ was tested in water (1:1). SMP buffer $\mathrm{pH}$ and exchangeable $\mathrm{Al}, \mathrm{Ca}$, and $\mathrm{Mg}$ contents (extracted by $\mathrm{KCl} 1 \mathrm{~mol} \mathrm{~L}^{-1}$ ) were conducted according to Tedesco et al. [37]. The Al was quantified by titration with $0.0125 \mathrm{~mol} \mathrm{~L}^{-1}$ $\mathrm{NaOH}$, and the $\mathrm{Ca}$ and $\mathrm{Mg}$ contents by atomic absorption spectrometry (AAS, Varian SpectrAA-600, Sydney, Australia). Soil tests for P, K, Cu, Zn, and Mn contents followed the Mehlich-1 method [37]. The P was quantified according to the method of Murphy and Riley [38], using a visible UV spectrometer (proanálise, UV-1600, Brasil, Porto Alegre), and the K by a flame photometer (Digimed, DM-62, Brasil, São Paulo). The $\mathrm{Cu}, \mathrm{Zn}$, and Mn were analyzed by atomic absorption spectrometry. Total organic carbon (TOC) content was determined using an elemental autoanalyzer (FlashEA 1112, Thermo Finnigan, Italy). Potential acidity $(\mathrm{H}+\mathrm{Al})$ was computed from the SMP index [39]. Soil aluminum and base saturation levels were calculated on a molar basis as percentages of the cation exchange capacity at pH $7.0\left(\mathrm{CEC}_{\mathrm{pH}} 7.0\right)[36]$.

Initial soil properties in 2004 were available only for the $0-10 \mathrm{~cm}$ layer [40]. Soil properties were as follows: $\mathrm{pH} 4.9,11 \mathrm{~g}$ organic carbon $\mathrm{kg}^{-1}, 814.4 \mathrm{~g}$ total $\mathrm{N} \mathrm{kg}^{-1}, 20.3 \mathrm{mg} \mathrm{P} \mathrm{kg}^{-1}$, $60 \mathrm{mg} \mathrm{K} \mathrm{kg}^{-1}, 160 \mathrm{mg} \mathrm{Ca} \mathrm{kg}^{-1}$, and $36 \mathrm{mg} \mathrm{Mg} \mathrm{kg}^{-1}$. Soil test P was high, while soil tests K, $\mathrm{Ca}$, and $\mathrm{Mg}$ were low for grain crops [36].

\subsection{Animal Manure Analyses}

Total $\mathrm{N}$ was extracted by digesting $2 \mathrm{~cm}^{3}$ of manure in natura in $2 \mathrm{~cm}^{3}$ of $\mathrm{H}_{2} \mathrm{SO}_{4}$ and $1 \mathrm{~cm}^{3}$ of $\mathrm{H}_{2} \mathrm{O}_{2}$ and analyzed by the Kjeldahl method [37]. Manures were oven-dried at $65{ }^{\circ} \mathrm{C}$ to determine the dry-matter (DM) content, then finely ground to determine total C using an elemental autoanalyzer. Compositions were analyzed as described above.

\subsection{Tissue Analyses}

The aboveground portions of the plants were collected at flowering, close to the soil surface, then oven-dried at $65{ }^{\circ} \mathrm{C}$ for biomass determination. Ground tissue was digested in a mixture of nitric and perchloric acids [41]. Total $\mathrm{K}, \mathrm{Ca}, \mathrm{Mg}, \mathrm{Cu}, \mathrm{Zn}$, and Mn were quantified according to Tedesco et al. [37]. Total $\mathrm{N}$ and $\mathrm{P}$ were extracted by sulfuric digestion. Total $\mathrm{N}$ was quantified using the Kjeldahl method [37], and total P using colorimetry [38]. We assumed that the dry matter of leftover crop residues contained $44 \%$ C [42].

\subsection{Grain and Biomass Production}

Grain yield and the production of aboveground plant materials were reported on a dry-weight basis $\left(65^{\circ} \mathrm{C}\right)$. Grain yield of maize was harvested in an area of $6.25 \mathrm{~m}^{2}$ in each plot and adjusted to $13 \%$ moisture content. Five maize plants were randomly collected per plot at flowering for the determination of aboveground dry matter. Plants of black oat were collected in an area of $2.00 \mathrm{~m}^{2}$ per plot. 


\subsection{Nutrient Budgets}

Contributions of plant parts to nutrient budgets were computed as the product of drymatter production and elemental concentration. The contribution of fertilizers and leftover crop residues to elemental budgets is presented in Supplementary Material Table S1.

\subsection{Climatic Indices}

Meteorological data were obtained from the Santa Maria (RS) meteorological station as daily minimum and maximum temperatures and daily precipitation per season. Summer and winter periods extended from October to April and from May through September, respectively. Seasonal temperature data were synthesized as monthly minimum and maximum temperatures as well as the number of degree-days (base $5^{\circ} \mathrm{C}$ for winter crops and base $10{ }^{\circ} \mathrm{C}$ for summer crops: Government of Canada, 2018). The distribution of daily rainfall events was expressed as the Shannon diversity index (SDI), as follows [43] (Equation (3)):

$$
S D I=\frac{-\sum_{i=1}^{n} p_{i} \times \ln \left(p_{i}\right)}{\ln (n)}
$$

where $p_{i}$ is the fraction of daily rainfall relative to total rainfall during the selected period and $n$ is the length of the selected period; $S D I=1$ indicates uniformly distributed rainfall (equal daily amount of rainfall during the selected period); $S D I=0$ indicates uneven rainfall (total rainfall concentrated in one day). Synthetic climatic indices are presented in Supplementary Material Figure S1 across 23 consecutive seasons starting in May (winter season) or September (summer season).

\subsection{Statistical Analysis}

Machine-learning models related features to target variables. Feature candidates were growing periods (1 to 22), climatic indexes, crops, nutrient sources, and nutrient dosages. Target variables were grain yield and aboveground dry matter.

We ran the gradient-boosting learner with cross-validation, since it outperformed the Random Forests, which are prone to overfitting data. Data extraction was stratified by treatment and accuracy was averaged by computing across ten runs $(\mathrm{k}=10)$ using the Orange 3.28 data-mining software. The $\mathrm{R}^{2}$, root mean square error (RMSE), and mean absolute error (MAE) were used as measures of accuracy. The RMSE and MAE were computed as follows:

$$
\begin{aligned}
\text { RMSE } & =\sqrt{\frac{1}{n} \sum_{i=1}^{n}(e i-m i)^{2}} \\
\text { MAE } & =\frac{1}{n} \sum_{i=1}^{n}|e i-m i|
\end{aligned}
$$

Soil test was related to nutrient budget as follows [5]:

$$
\Delta \text { soiltest }=f(\text { Input }- \text { Offtake })
$$

where inputs were fertilization treatments and offtake was total amount of nutrients exported through grain harvest (nutrient concentrations times grain biomass). Nutrients from leftover residues were considered as recycled by the system. Nutrient inputs and offtakes, and the corresponding nutrient budgets, were recorded across the cropping seasons (2009-2020).

Soil analyses were performed at four occasions every four years, starting in May 2009 (end of the 2008 summer season) before oilseed winter cultivation and ending in April 2020 after the summer maize crop (end of the 2019 summer season). The first period (1-6) comprised six cropping seasons. The second period (7-14) and the last period (15-22) comprised eight cropping seasons each. Inputs, offtakes, and soil tests included C, N, P, K, $\mathrm{Ca}, \mathrm{Mg}, \mathrm{Cu}, \mathrm{Zn}$, and $\mathrm{Mn}$; hence, nine elements. 
Apparent nutrient recovery efficiency (ANR) reflects a plant's ability to acquire applied nutrients [15]. In this paper, apparent nutrient recovery (ANR) from the organic fertilization was computed against mineral fertilization as a control rather than a zero control [15], as follows (Equation (7)):

$$
\operatorname{ANR}(\%)=\frac{\text { Nutrientuptake }_{\text {manure }}-\text { Nutrientuptake }_{N P K}}{\text { Nutrientapplied }_{\text {manure }}-\text { Nutrientapplied }_{N P K}} \times 100
$$

This new formulation of ANR measures the marginal gain in crop nutrient uptake under N-based manure fertilization regimes compared to the mineral fertilization. If ANR $>100 \%$, the crop takes up more nutrients from N-based manure fertilization applied in excess of mineral fertilization. Such a relative ANR index provides a measure of a plant's capacity to mop up nutrient excess and prevent environmental damage.

\section{Results}

\subsection{Machine-Learning Models}

The growing period alone could not predict grain yield and the production of aboveground dry matter (Table 2). Growing periods can be viewed as synthetic, integrating climatic indices and the length of the growing season. Adding crops did not improve the accuracy. The source of the nutrient increased the model accuracy, but the nutrient dosage increased it even more. The accuracy reached its highest value when growing periods, fertilizer sources, and dosage were used as features to predict grain yield and aboveground biomass.

Table 2. Relationships between target variables and features using gradient boosting.

\begin{tabular}{ccccccc}
\hline \multirow{2}{*}{ Feature } & \multicolumn{3}{c}{ Grain Yield } & \multicolumn{3}{c}{ Aboveground Dry Matter } \\
\cline { 2 - 7 } & ${ }^{*}$ RMSE & $*$ * MAE & $\mathbf{R}^{\mathbf{2}}$ & RMSE & MAE & $\mathbf{R}^{\mathbf{2}}$ \\
\hline Period & 1.849 & 1.375 & 0.569 & 1.687 & 1.239 & 0.630 \\
Period + crop & 1.847 & 1.370 & 0.570 & 1.689 & 1.228 & 0.637 \\
Period + source & 0.748 & 0.553 & 0.930 & 0.981 & 0.699 & 0.875 \\
$\begin{array}{c}\text { Period + source + } \\
\text { dosage }\end{array}$ & 0.593 & 0.436 & 0.956 & 0.703 & 0.481 & 0.936 \\
\hline
\end{tabular}

* Root mean square error $\left(\mathrm{Mg} \mathrm{ha}^{-1}\right) .{ }^{* *}$ Mean absolute error $\left(\mathrm{Mg} \mathrm{ha}^{-1}\right)$.

\subsection{Grain Yield and Aboveground Biomass}

The average yields of maize and black oat were low in the control treatment (Table 3). The yields were smaller under the mineral than the organic fertilization regimes. Pig slurry produced the highest crop yields, providing $21 \%$ more maize grain yield and $23 \%$ more aboveground oat biomass compared to the mineral fertilization.

\subsection{Change in Soil $p H$}

The treatments impacted the soil $\mathrm{pH}$ in both the $0-10 \mathrm{~cm}$ and $10-20 \mathrm{~cm}$ layers (Figure 1 ). Compared to the initial $\mathrm{pH}$ of 4.9 in the $0-10 \mathrm{~cm}$ layer at the onset of the experiment in 2004, the $\mathrm{pH}$ decreased then stabilized in the control treatment, decreased systematically under the mineral fertilization treatment, and fluctuated about the mean under the organic fertilization treatment. The application of pig deep litter increased the soil $\mathrm{pH}$ by 0.7 units compared to the control treatment in the $0-10 \mathrm{~cm}$ layer. In the treatments with the application of pig slurry and cattle slurry, the soil $\mathrm{pH}$ increased by 0.35 and 0.20 units, respectively, in the 0-10 cm layer compared to the control. The treatments had similar impacts on the soil $\mathrm{pH}$ in the 10-20 cm layer, where pig deep litter showed the greatest capacity to increase the soil $\mathrm{pH}$. From 2012 onwards, mineral fertilization significantly reduced the soil $\mathrm{pH}$ to values less than 4.7 in the $10-20 \mathrm{~cm}$ layer. 
Table 3. Mean and standard deviation (SD) of grain and aboveground crop residues as related to fertilizer source during 11 years of experimentation $(n=36)$.

\begin{tabular}{ccccccc}
\hline & \multicolumn{3}{c}{ Maize } & \multicolumn{2}{c}{ Avena } \\
\hline $\begin{array}{c}\text { Fertilizer } \\
\text { Source }\end{array}$ & Grain & \multicolumn{3}{c}{ Aboveground Crop Residues } & Aboveground Crop Residues \\
\hline \multicolumn{1}{c}{} & Mean & SD & Mean & SD & Mean & SD \\
\hline $\begin{array}{c}\text { Control ha } \\
\mathbf{- 1}\end{array}$ & 2.92 & 1.17 & 4.03 & 1.29 & 1.66 & 0.55 \\
$\begin{array}{c}\text { Mineral } \\
\text { fertilizer }\end{array}$ & 6.10 & 1.71 & 7.13 & 2.10 & 3.24 & 0.74 \\
$\begin{array}{c}\text { Cattle } \\
\text { slurry }\end{array}$ & 6.99 & 1.75 & 8.05 & 2.32 & 3.63 & 0.87 \\
$\begin{array}{c}\text { Pig deep } \\
\text { litter }\end{array}$ & 7.20 & 2.18 & 7.65 & 2.84 & 3.73 & 0.85 \\
$\begin{array}{c}\text { Pig } \\
\text { slurry }\end{array}$ & 7.40 & 2.54 & 8.76 & 2.97 & 4.00 & 0.71 \\
\hline
\end{tabular}
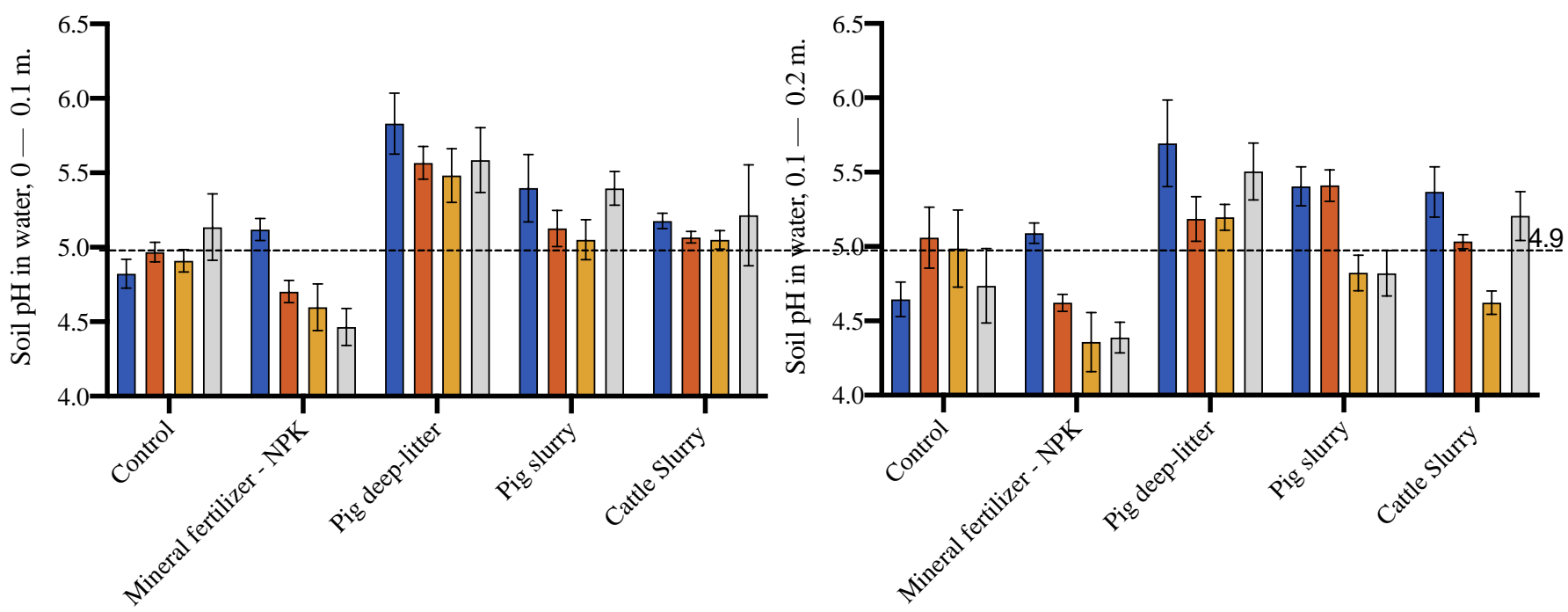

Figure 1. Change in soil $\mathrm{pH}$ in the $0-0.1 \mathrm{~m}$ and $0.1-0.2 \mathrm{~m}$ layers between soil sampling periods as impacted by fertilizer sources. Horizontal line shows initial soil $\mathrm{pH}$ in 2004 . The results shown in the figure are the arithmetic mean and standard error based on $\mathrm{pH}$ values.

\subsection{Change in Soil $C$ and $N$ Content}

Changes in the soil $C$ content depended on the amount of $C$ input provided by the organic fertilizers and crop residues (Figure 2a,b). The initial soil C content was $11 \mathrm{~g} \mathrm{C} \mathrm{kg}^{-1}$ in 2004. The $\mathrm{C}$ inputs with the sole contribution of crop residues were in the following order: pig deep litter $>$ cattle slurry $>$ pig slurry $>$ mineral fertilizer alone $>$ control (Supplemental Materials Table S1). In the $0-10 \mathrm{~cm}$ layer, soil test $C$ showed linear increase with $C$ additions. In the control treatment, the $\mathrm{C}$ content in the soil tended to decrease with the $\mathrm{C}$ additions, indicating a negative carbon budget. Where mineral fertilizer (NPK) was applied, the $C$ budget stabilized. Where organic fertilizers were applied, there was a sharp increase in the $C$ content of the soil in the $0-10 \mathrm{~cm}$ layer, where the cumulated $C$ additions exceeded $50 \mathrm{Mg} \mathrm{C} \mathrm{ha}{ }^{-1}$. The application of pig deep litter increased the soil C content by $132 \%$ in the $0-10 \mathrm{~cm}$ layer and by $14 \%$ in the $10-20 \mathrm{~cm}$ layer. While the organic inputs increased the 
soil C content in the 10-20 cm layer compared to the control, the magnitude of the change was much smaller and more variable than in the $0-10 \mathrm{~cm}$ layer.

\section{Control Mineral fertilizer-NPK Pig deep-litter Pig slurry Cattle slurry}

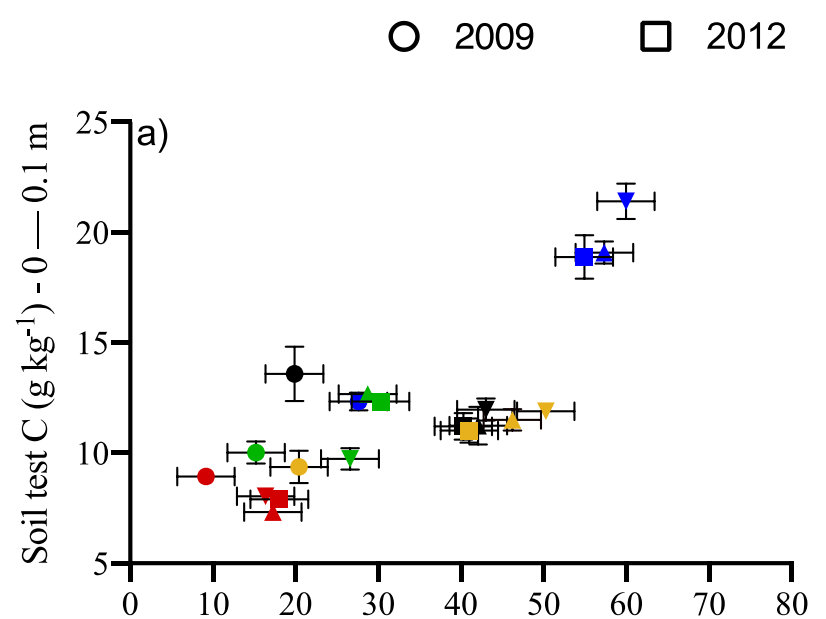

Cumulated $\mathrm{C}$ additions during control period $\left(\mathrm{t} \mathrm{ha}^{-1}\right)$
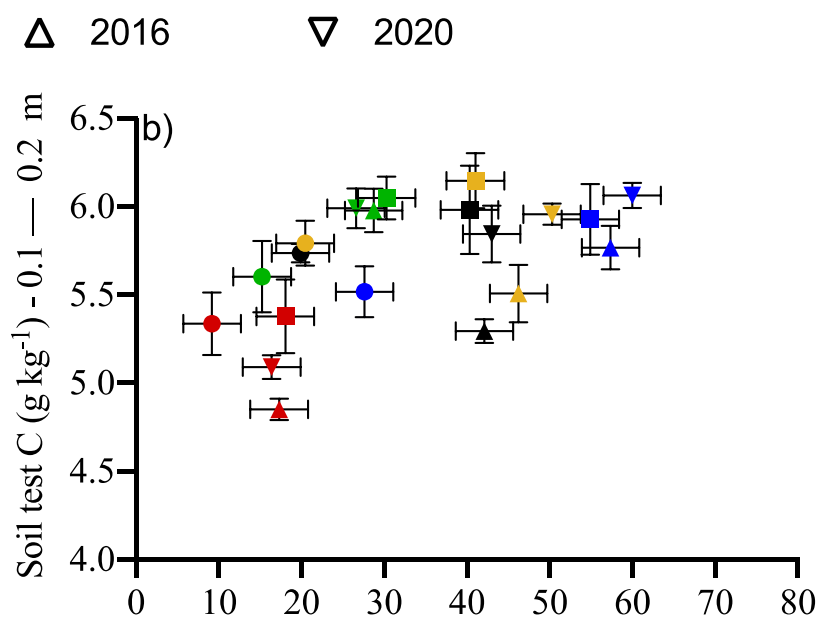

Cumulated $\mathrm{C}$ additions during control period $\left(\mathrm{t} \mathrm{ha}^{-1}\right)$

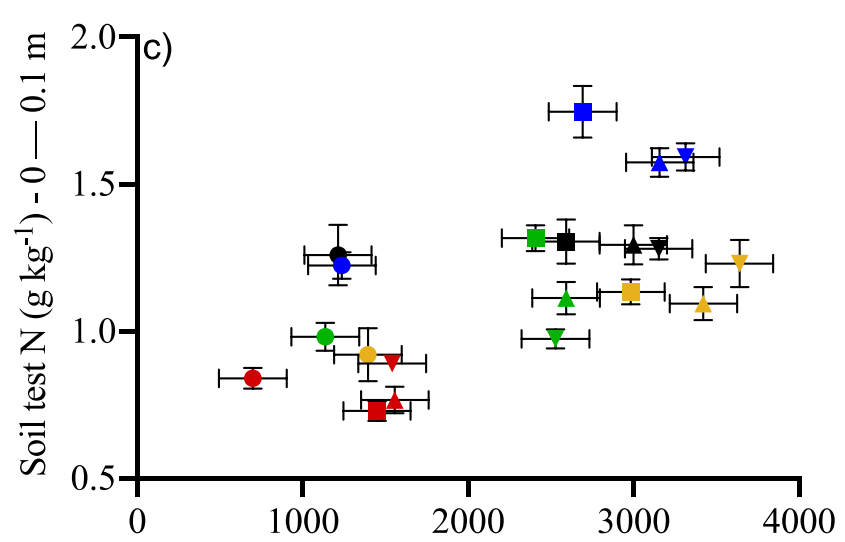

Cumulated $\mathrm{N}$ additions during control period $\left(\mathrm{t} \mathrm{ha}^{-1}\right)$

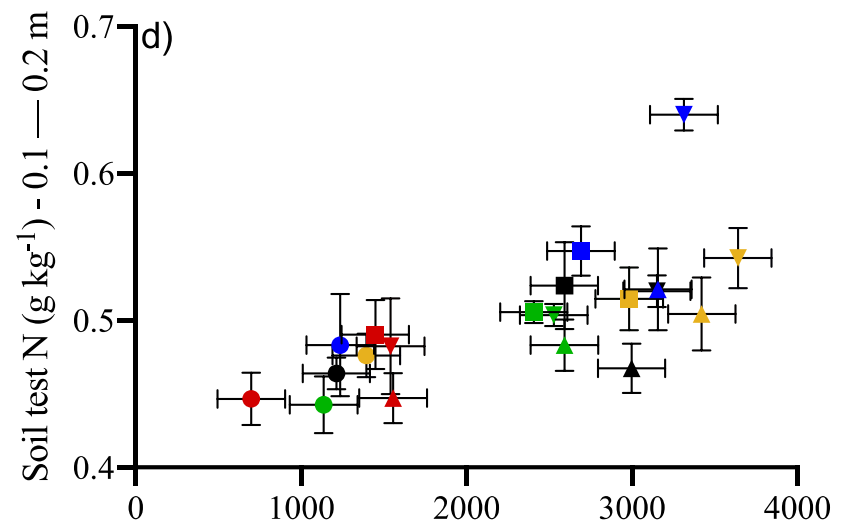

Cumulated $\mathrm{N}$ additions during control period $\left(\mathrm{t} \mathrm{ha}^{-1}\right)$

Figure 2. Change in soil C (a,b) and N (c,d) content during the 2009-2020 period in the 0-0.1 and 0.1-0.2 m layers, respectively, as impacted by treatments. Error bars represent standard errors of the means.

The soil $\mathrm{N}$ content changed little in the control treatment between periods but increased with the $\mathrm{N}$ additions (Figure $2 \mathrm{c}, \mathrm{d}$ ). The $\mathrm{N}$ source impacted the soil $\mathrm{N}$ differently in the $0-10$ and 10-20 cm layers. In the 0-10 cm layer, pig deep litter was the most efficient $\mathrm{N}$ source, followed by cattle slurry and pig slurry. Mineral fertilization accumulated the least N. Pig slurry and pig deep litter increased the soil $\mathrm{N}$ by 1.95 and 1.40 times in the $0-10 \mathrm{~cm}$ layer, with the additions of 2.5 and $3.2 \mathrm{Mg} \mathrm{N} \mathrm{ha}^{-1}$, respectively, over 16 years. The pig deep-litter treatment showed the largest $\mathrm{N}$ accumulation in the 10-20 cm layer, while the other $\mathrm{N}$ sources produced similar results.

\subsection{Change in Soil $P, K, C a$, and $\mathrm{Mg}$ Content}

During the experiment, the soil received 2.69, 3.23, 2.05, and $0.43 \mathrm{Mg} \mathrm{P} \mathrm{ha}^{-1}$ from pig deep litter, pig slurry, cattle slurry, and mineral fertilizer, respectively (Supplemental Materials Table S1). The soil P ranged from 6.6 to $108.5 \mathrm{mg} \mathrm{P} \mathrm{kg}^{-1}$ in the $0-10 \mathrm{~cm}$ layer 
and changed drastically where P additions exceeded 1.0-1.2 $\mathrm{Mg} \mathrm{P} \mathrm{ha}^{-1}$ (Figure 3a). Pig deep-litter and pig slurry increased the soil $P$ by a factor of 2 in the $0-10 \mathrm{~cm}$ layer compared to mineral fertilization. The soil $\mathrm{P}$ in the $10-20 \mathrm{~cm}$ layer was most impacted by pig deep litter (Figure $3 \mathrm{~b}$ ), because the larger amounts of applied $\mathrm{P}$ favored the migration of $\mathrm{P}$ deeper into the soil profile. The application of pig slurry increased the soil $\mathrm{P}$ in the 10-20 cm layer by more than 7 times compared to mineral fertilization.

The contents of the other macronutrients in the soil increased by different amounts between the soil layers depending on the nutrient source and dosage (Figure $3 c-h$ ). Pig deep litter, pig slurry, cattle slurry, and mineral fertilizer increased the soil $\mathrm{K}$ compared to the control (Figure 3c,d). There were sharp increases in the soil $\mathrm{K}$ in the $0-10$ and $10-20 \mathrm{~cm}$ layers, where the $\mathrm{K}$ additions exceeded $3.5 \mathrm{Mg} \mathrm{K} \mathrm{ha}^{-1}$. The soil $\mathrm{K}$ in the $0-10 \mathrm{~cm}$ layer in the control treatment averaged $30 \mathrm{mg} \mathrm{K} \mathrm{kg}^{-1}$. Pig deep litter, cattle slurry, and pig slurry increased the $\mathrm{K}$ levels by 93,52 , and $5 \%$, respectively, compared to mineral fertilization. The soil $\mathrm{K}$ in the $10-20 \mathrm{~cm}$ layer was increased by pig deep litter, cattle slurry, pig slurry, and mineral fertilization.

The soil Ca increased due to positive budgets in the $0-10$ and $10-20 \mathrm{~cm}$ layers (Figure 3e,f). Pig deep litter increased the soil Ca by 1.33, 1.53, and 2.42 times in the 0-10 cm layer compared to cattle slurry, pig slurry, and mineral fertilization, respectively. There was a smaller increase in the soil Ca in the 10-20 cm layer. Depending on the fertilizer source, the soil $\mathrm{Mg}$ showed increasing trends or no trend in the $0-10 \mathrm{~cm}$ and $10-20 \mathrm{~cm}$ layers, where the $\mathrm{Mg}$ budgets were positive (Figure 3g,h). The treatments that provided the greatest $\mathrm{Mg}$ increments in the $0-10 \mathrm{~cm}$ and the $10-20 \mathrm{~cm}$ layers were cattle slurry, pig deep-litter, and pig slurry.

\subsection{Change in Soil Micronutrient Content ( $\mathrm{Cu}, \mathrm{Zn}, \mathrm{Mn}$ )}

The soil received 22, 27, and $16 \mathrm{~kg} \mathrm{Cu} \mathrm{ha}^{-1}$ and 107, 92, and $29 \mathrm{~kg} \mathrm{Zn} \mathrm{ha}^{-1}$ through the application of pig deep litter, pig slurry, and cattle slurry, respectively, during the experimental period ( Supplemental Materials Table S1). The soil $\mathrm{Cu}$ and $\mathrm{Zn}$ increased in the $0-10$ and 10-20 cm layers at rates depending on the fertilizer source and dosage (Figure $4 \mathrm{a}-\mathrm{d}$ ). Where the soil $\mathrm{Cu}$ values were small, the confidence intervals may have zero overlap due to the small numbers and the statistical distortion where the concentrations were not log-ratio-transformed (see Filzmoser et al. [44]). Pig deep litter increased the soil $\mathrm{Cu}$ and $\mathrm{Zn}$ by 1.52 and 2.5 times, respectively, compared to the treatment with the application of pig slurry. The magnitude of increase in the soil $\mathrm{Cu}$ and $\mathrm{Zn}$ was much smaller in the 10-20 than in the $0-10 \mathrm{~cm}$ layers. Pig deep litter and pig slurry produced the largest increments.

The soil Mn tended to be stable across the soil layers, fertilizer sources, and Mn doses (Figure 4e,f). During the evaluation in 2020, the soil Mn increased significantly in the $0-10 \mathrm{~cm}$ layer with the application of pig deep litter, cattle slurry, and pig slurry. In the 10-20 cm layer, the soil Mn was similar among all treatments except for the control. The soil Mn may have been affected indirectly by changes in the soil $\mathrm{pH}$.

\subsection{Nutrient-Use Efficiency}

The ANR values computed using mineral fertilization as a benchmark were positive across the macronutrients, indicating the additional uptake of the manure nutrients applied in excess of mineral fertilization (Table 4). The ANR for $\mathrm{N}$ was much higher for pig deep litter compared to cattle and pig slurries. For N, pig deep litter also returned the highest ANR in the aboveground portions of the plants. Pig slurry showed the highest ANR for $\mathrm{P}$, $\mathrm{K}, \mathrm{Ca}$, and $\mathrm{Mg}$.

The shoot ANR for the micronutrients varied according to the organic source (Table 4). The ANR of the micronutrients was substantial, indicating the beneficial potential of organic fertilizers for feed biofortification, as long as soil contamination is avoided. The high ANR values for the micronutrients indicated the fertilizers' high potential for correcting the $\mathrm{Cu}$, Zn, and Mn deficiency in Typic Hapludalf soil. 
Control Mineral fertilizer-NPK Pig deep-litter Pig slurry Cattle slurry

○ $2009 \quad \square 2012$

$\triangle 2016 \quad \nabla 2020$
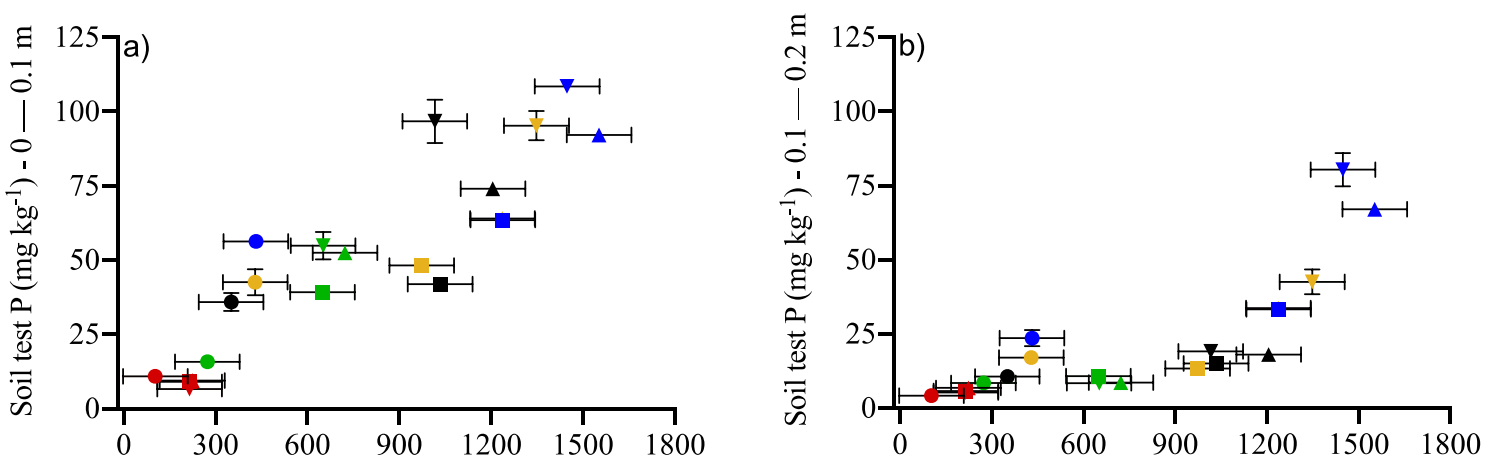

Cumulated $\mathrm{P}$ additions during control period $\left(\mathrm{kg} \mathrm{P} \mathrm{ha}^{-1}\right)$

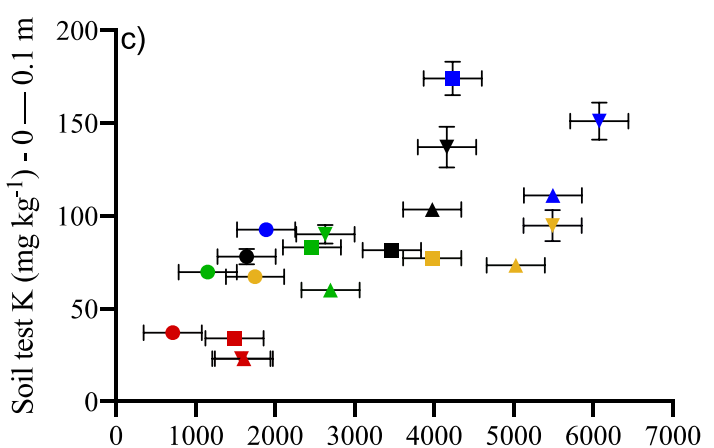

Cumulated $\mathrm{P}$ additions during control period $\left(\mathrm{kg} \mathrm{P} \mathrm{ha}^{-1}\right)$

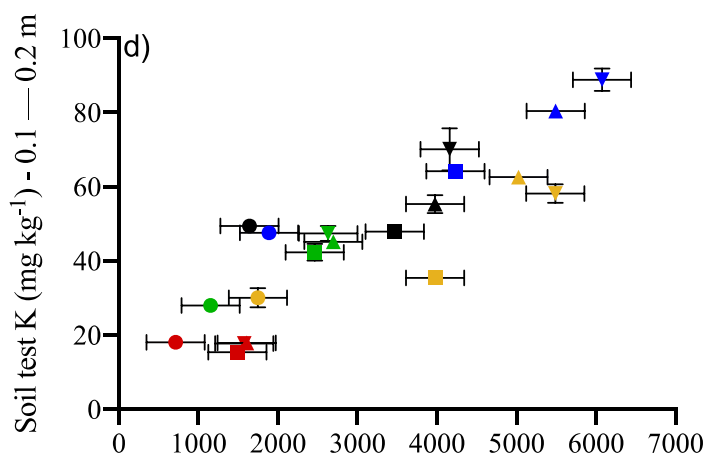

Cumulated $\mathrm{K}$ additions during control period $\left(\mathrm{kg} \mathrm{K} \mathrm{ha}^{-1}\right)$

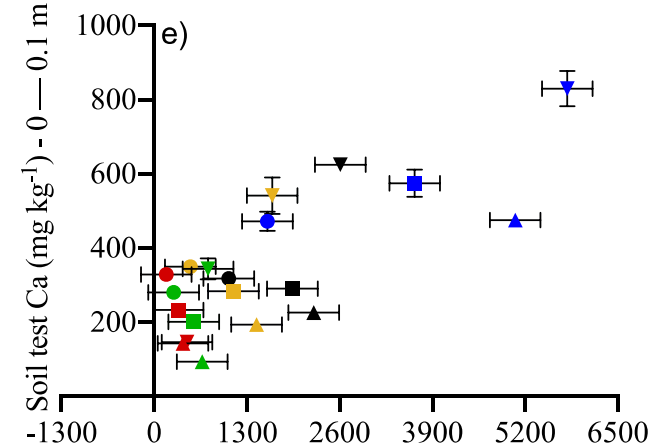

Cumulated $\mathrm{K}$ additions during control period $\left(\mathrm{kg} \mathrm{K} \mathrm{ha}^{-1}\right)$

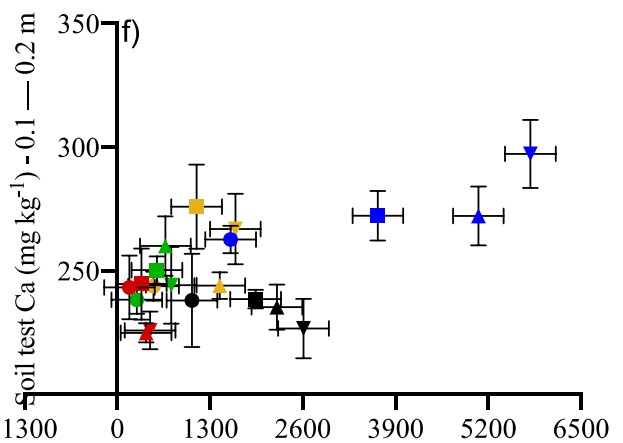

Cumulated $\mathrm{Ca}$ additions during control period $\left(\mathrm{kg} \mathrm{Ca} \mathrm{ha}^{-1}\right)$

Cumulated $\mathrm{Ca}$ additions during control period $\left(\mathrm{kg} \mathrm{Ca} \mathrm{ha}^{-1}\right)$
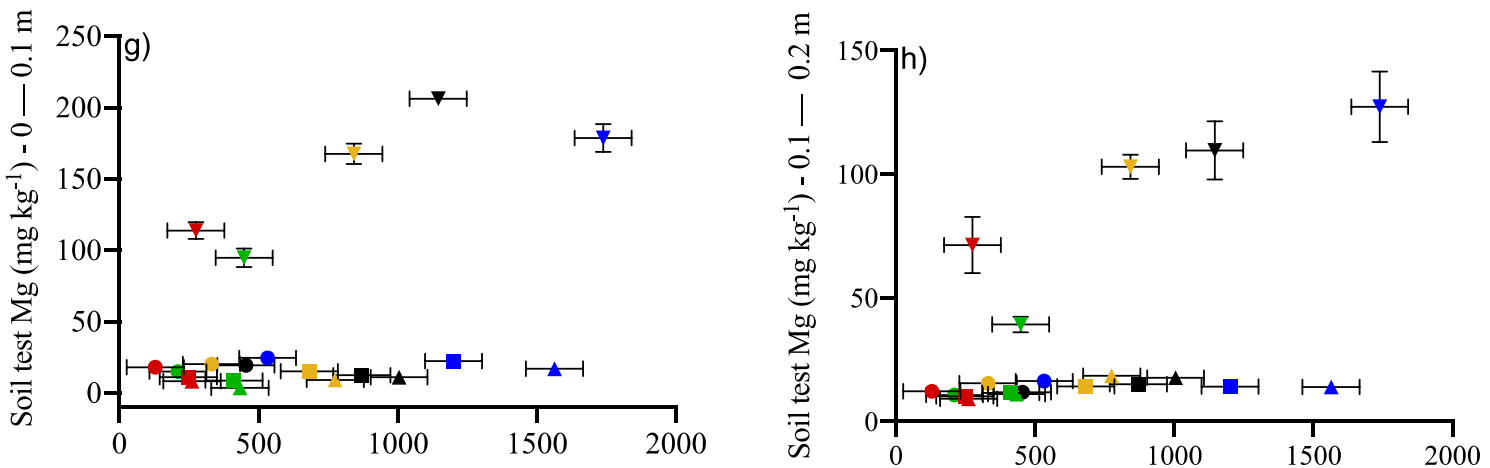

Cumulated $\mathrm{Mg}$ additions during control period $\left(\mathrm{kg} \mathrm{Mg} \mathrm{ha}^{-1}\right)$

Cumulated $\mathrm{Mg}$ additions during control period $\left(\mathrm{kg} \mathrm{Mg} \mathrm{ha}^{-1}\right)$

Figure 3. Change in soil $\mathrm{P}(\mathbf{a}, \mathbf{b}), \mathrm{K}(\mathbf{c}, \mathbf{d})$, Ca (e,f), and $\mathrm{Mg}(\mathbf{g}, \mathbf{h})$ during the 2009-2020 period in the 0-0.1 and 0.1-0.2 m layers, respectively, as impacted by treatments. Error bars represent standard errors of the means. 
Control Mineral fertilizer-NPK Pig deep-litter Pig slurry Cattle slurry
O 2009
2012
$\Delta 2016$
$\nabla \quad 2020$

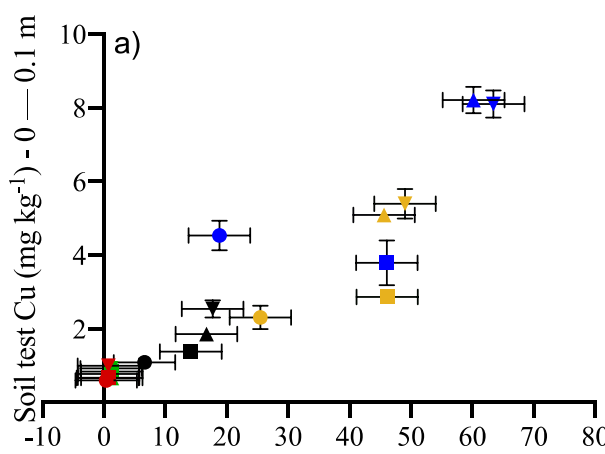

Cumulated $\mathrm{Cu}$ additions during control period $\left(\mathrm{kg} \mathrm{Cu} \mathrm{ha}^{-1}\right)$

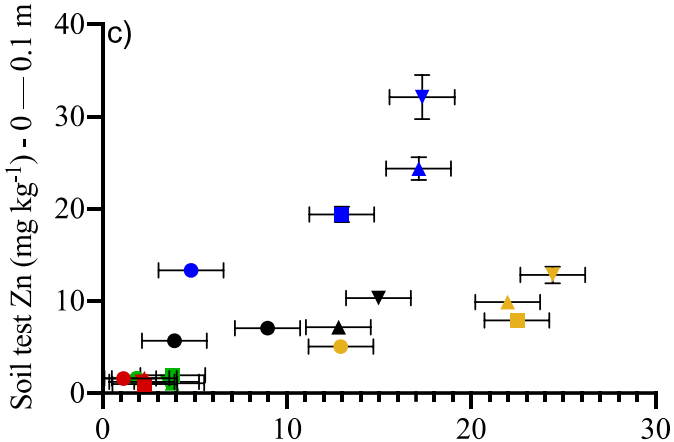

Cumulated $\mathrm{Zn}$ additions during control period $\left(\mathrm{kg} \mathrm{Zn} \mathrm{ha}^{-1}\right)$

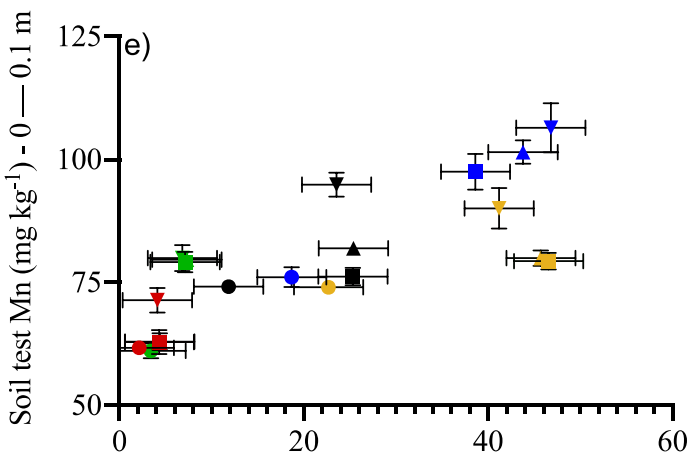

Cumulated Mn additions during control period $\left(\mathrm{kg} \mathrm{Mn} \mathrm{ha}^{-1}\right)$

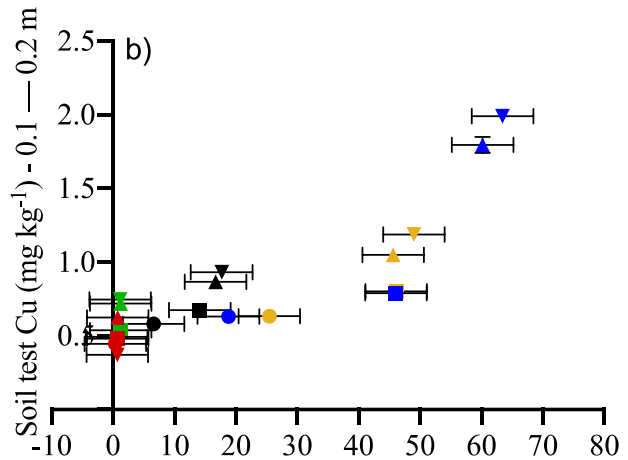

Cumulated $\mathrm{Cu}$ additions during control period $\left(\mathrm{kg} \mathrm{Cu} \mathrm{ha}^{-1}\right)$

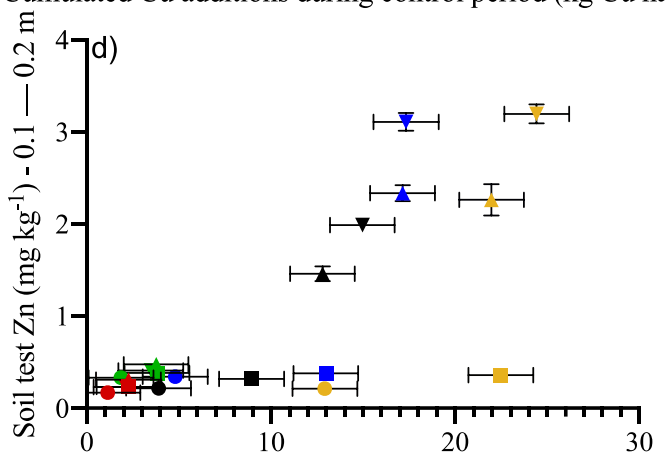

Cumulated $\mathrm{Zn}$ additions during control period $\left(\mathrm{kg} \mathrm{Zn} \mathrm{ha}^{-1}\right)$

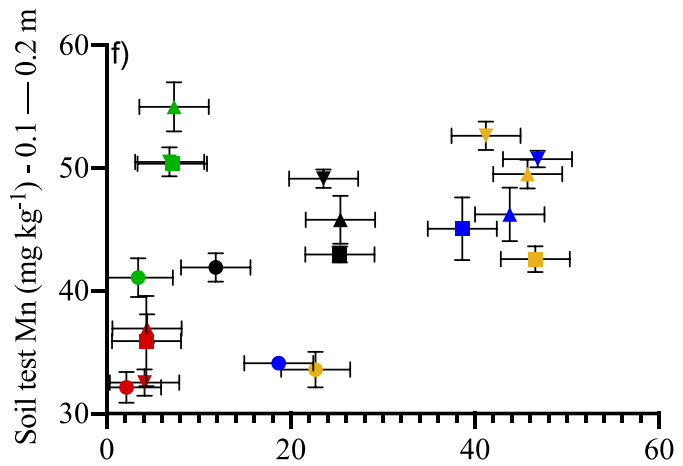

Cumulated Mn additions during control period $\left(\mathrm{kg} \mathrm{Mn} \mathrm{ha}^{-1}\right)$

Figure 4. Change in the soil $\mathrm{Cu}(\mathbf{a}, \mathbf{b}), \mathrm{Zn}(\mathbf{c}, \mathbf{d})$, and Mn (e,f) during the 2009-2020 period in the 0-0.1 and 0.1-0.2 m layers, respectively, as impacted by fertilizer regimes. Error bars represent standard errors of the means. 
Table 4. Apparent nutrient recovery (ANR) of N-based manure fertilization compared to mineral fertilization (NPK).

\begin{tabular}{|c|c|c|c|c|c|c|c|c|}
\hline \multirow{2}{*}{$\begin{array}{l}\text { Manure } \\
\text { Source }\end{array}$} & $\mathbf{N}$ & $\mathbf{P}$ & $\mathbf{K}$ & $\mathrm{Ca}$ & $\mathrm{Mg}$ & $\mathrm{Cu}$ & $\mathrm{Zn}$ & Mn \\
\hline & \multicolumn{8}{|c|}{$\%$ (Mean \pm Standard Deviation) } \\
\hline & \multicolumn{8}{|c|}{ 2009-2012 period-Dry matter } \\
\hline $\begin{array}{l}\text { Cattle } \\
\text { slurry }\end{array}$ & $3 \pm 2$ & $5 \pm 3$ & $30 \pm 11$ & $4 \pm 2$ & $8 \pm 4$ & $1862 \pm 862$ & $2327 \pm 1256$ & $3778 \pm 1274$ \\
\hline $\begin{array}{l}\text { Pig deep } \\
\text { litter }\end{array}$ & $50 \pm 16$ & $7 \pm 3$ & $21 \pm 7$ & $2 \pm 1$ & $7 \pm 2$ & $1651 \pm 535$ & $1203 \pm 404$ & $3056 \pm 1049$ \\
\hline \multirow[t]{2}{*}{ Pig slurry } & $15 \pm 4$ & $40 \pm 14$ & $55 \pm 12$ & $28 \pm 6$ & $52 \pm 17$ & $2351 \pm 689$ & $2620 \pm 906$ & $4802 \pm 871$ \\
\hline & \multicolumn{8}{|c|}{ 2012-2016 period-Dry matter } \\
\hline $\begin{array}{l}\text { Cattle } \\
\text { slurry }\end{array}$ & $4 \pm 1$ & $25 \pm 6$ & $62 \pm 10$ & $18 \pm 2$ & $24 \pm 4$ & $1785 \pm 412$ & $3722 \pm 917$ & $7575 \pm 1500$ \\
\hline $\begin{array}{l}\text { Pig deep } \\
\text { litter }\end{array}$ & $179 \pm 13$ & $14 \pm 2$ & $25 \pm 2$ & $7 \pm 0.2$ & $15 \pm 0.3$ & $1993 \pm 331$ & $1377 \pm 227$ & $3530 \pm 682$ \\
\hline \multirow[t]{2}{*}{ Pig slurry } & $30 \pm 5$ & $24 \pm 6$ & $55 \pm 7$ & $86 \pm 10$ & $127 \pm 21$ & $2034 \pm 452$ & $2648 \pm 681$ & $6599 \pm 902$ \\
\hline & \multicolumn{8}{|c|}{ 2016-2020 period-Dry matter } \\
\hline $\begin{array}{l}\text { Cattle } \\
\text { slurry }\end{array}$ & $5 \pm 1$ & $26 \pm 5$ & $73 \pm 9$ & $20 \pm 2$ & $27 \pm 4$ & $2160 \pm 414$ & $4427 \pm 954$ & $8685 \pm 1174$ \\
\hline $\begin{array}{l}\text { Pig deep } \\
\text { litter }\end{array}$ & $199 \pm 20$ & $15 \pm 2$ & $30 \pm 3$ & $7 \pm 0.2$ & $17 \pm 1$ & $2360 \pm 454$ & $1603 \pm 313$ & $4145 \pm 754$ \\
\hline \multirow[t]{2}{*}{ Pig slurry } & $36 \pm 6$ & $28 \pm 7$ & $73 \pm 11$ & $100 \pm 14$ & $147 \pm 26$ & $2592 \pm 557$ & $3276 \pm 806$ & $10000 \pm 1446$ \\
\hline & \multicolumn{8}{|c|}{ 2009-2012 period-Grains } \\
\hline $\begin{array}{l}\text { Cattle } \\
\text { slurry }\end{array}$ & $1.5 \pm 1$ & $4 \pm 2$ & $4 \pm 2$ & $0.3 \pm 0.1$ & $2 \pm 1$ & $124 \pm 49$ & $1243 \pm 495$ & $199 \pm 79$ \\
\hline $\begin{array}{l}\text { Pig deep } \\
\text { litter }\end{array}$ & $34 \pm 3$ & $7 \pm 1$ & $5 \pm 0.4$ & $0.2 \pm 0.1$ & $3 \pm 0.2$ & $166 \pm 13$ & $858 \pm 68$ & $319 \pm 25$ \\
\hline \multirow[t]{2}{*}{ Pig slurry } & $3 \pm 1$ & $14 \pm 2$ & $4 \pm 1$ & $1 \pm 0.2$ & $7 \pm 1$ & $79 \pm 14$ & $654 \pm 115$ & $149 \pm 26$ \\
\hline & \multicolumn{8}{|c|}{ 2012-2016 period-Grains } \\
\hline $\begin{array}{l}\text { Cattle } \\
\text { slurry }\end{array}$ & $1 \pm 0.1$ & $9 \pm 2$ & $6 \pm 2$ & $1 \pm 0.2$ & $3 \pm 1$ & $174 \pm 50$ & $1194 \pm 307$ & $510 \pm 142$ \\
\hline $\begin{array}{l}\text { Pig deep } \\
\text { litter }\end{array}$ & $72 \pm 3$ & $8 \pm 0.4$ & $5 \pm 0.2$ & $1 \pm 0.2$ & $3 \pm 0.1$ & $293 \pm 10$ & $727 \pm 34$ & $419 \pm 14$ \\
\hline \multirow[t]{2}{*}{ Pig slurry } & $5 \pm 1$ & $7 \pm 1$ & $4 \pm 1$ & $3 \pm 1$ & $13 \pm 3$ & $106 \pm 28$ & $618 \pm 116$ & $269 \pm 65$ \\
\hline & \multicolumn{8}{|c|}{ 2016-2020 period-Grains } \\
\hline $\begin{array}{l}\text { Cattle } \\
\text { slurry }\end{array}$ & $1 \pm 0.2$ & $8 \pm 2$ & $7 \pm 2$ & $1 \pm 0.3$ & $4 \pm 1$ & $187 \pm 54$ & $1283 \pm 330$ & $504 \pm 140$ \\
\hline $\begin{array}{l}\text { Pig deep } \\
\text { litter }\end{array}$ & $75 \pm 3$ & $8 \pm 0.4$ & $5 \pm 0.2$ & $1 \pm 0.02$ & $4 \pm 0.1$ & $316 \pm 10$ & $784 \pm 37$ & $431 \pm 15$ \\
\hline Pig slurry & $5 \pm 1$ & $7 \pm 1$ & $4 \pm 1$ & $3 \pm 1$ & $13 \pm 3$ & $111 \pm 29$ & $643 \pm 120$ & $313 \pm 76$ \\
\hline
\end{tabular}

\section{Discussion}

\subsection{Crop Performance}

Crop performance was impacted by the fertilizer source and dosage. The acid Typic Hapludalf under study appeared to be low in natural fertility, as shown by the low crop yields in the control treatment. Hence, the zero- $\mathrm{N}$ fertilization control could not be used as a benchmark treatment to compute the ANR, because it failed to meet the ceteris paribus assumption that all the factors except $\mathrm{N}$ were equal or at optimum levels [45]. The manures returned higher yields than the mineral fertilizers, through which only $\mathrm{N}, \mathrm{P}$, and $\mathrm{K}$ were applied. The mineral (NPK) fertilization regime met the ceteris paribus assumption for $\mathrm{N}, \mathrm{P}$, and $\mathrm{K}$ based on regional recommendations [36]; however, it showed an apparent shortage in the other elements. 
Organic fertilization supplied macro- and micronutrients during the entire crop cycle. The higher nutrient-use efficiency with organic manuring is attributable in part to the increased activity of the soil microbial community that plays a critical role in the subsequent cycling and transformation of nutrients [46]. The labile $C$ present in the organic residues promoted microbial activity and improved the soil's physical properties [47-49]. While organic matter addition through crop residues and manures increases the water-soluble and -exchangeable forms of micronutrients in soil and the uptake of micronutrients, a high organic matter content in soils results in more stable complexes of micronutrients [11]. The bioavailability of micronutrients thus varies largely from the time of the application of fresh manure to the time of organic matter stabilization in the soil.

The accumulation of phosphorus and the changing patterns of micronutrient bioavailability require regular monitoring to avoid environmental damage and contamination by heavy metals with potential adverse effects on soil health and food safety in the long run $[50,51]$. Indeed, $\mathrm{N}$-based fertilization with manures appeared to be unsustainable and could be replaced by P-based fertilization [7]. Composting organic byproducts and mixing and granulating composts with mineral matrices, where the concentration of phosphorus and micronutrients can be adjusted industrially, has also been suggested [52-56].

\subsection{Soil Carbon}

Typic Hapludalf soils are subjected to erosion and yield loss in southern Brazil [57], and this can be tackled by soil C. Soil C impacts soil quality, functionality, and health and reduces soil erosion [58]. Leftover crop residues, green manures, and organic fertilizers are the primary sources of soil $C$ in agroecosystems [59]. An increase in soil C, in addition to benefiting soil quality and crop yields, plays an important role in mitigating global warming $[60,61]$. While the contribution of crop residues and green manures under the mineral fertilization regime sufficed to maintain the soil carbon level, adding manure as a fertilizer source increased the soil $C$ levels above those of crop residues alone, especially where pig deep litter was added as a high-C manure [13,62].

\subsection{Soil Test Levels}

The mineral fertilization regime acidified the soil through urea transformation [63]. In soils with $\mathrm{pH}$ values lower than 5.5 , the release of toxic free aluminum $\left(\mathrm{Al}^{3+}\right)$ inhibits the growth and absorption of water and nutrients by the root system [64]. Under such conditions, the bioavailability of essential nutrients is reduced, mainly that of $\mathrm{N}, \mathrm{P}, \mathrm{Mg}$, $\mathrm{Ca}$, and Mo $[65,66]$. Organic sources increased or maintained the soil $\mathrm{pH}$ above the initial level through the adsorption of $\mathrm{H}^{+}$ions by organic compounds [13]. The positive effect of manures in neutralizing soil acidity has been reported for other organic materials [67] but requires mineralization over several months to reach maximum effectiveness [68].

The buildup of soil nutrients to critical and maintenance levels is an objective of soil testing [69]. However, building the soil $\mathrm{P}$ to excessive levels leads to the eutrophication of surface waters [29]. The soil P tends to increase in upper soil layers depending on the P budget [70-72], increasing the risk of P loss by runoff [21,73]. Messiga et al. [5] and Damar et al. [31] revealed different facets of soil P changes over time in long-term experiments involving no-till soils and mineral vs. organic fertilization regimes, especially in gleysolic soils showing a low P-retention capacity. For the N-based fertilization of ley-farming systems, there was a greater P accumulation under MIN (mineral) than LDM (liquid dairy manure), and under CP (chisel plowing) than MP (moldboard plowing). The P legacy from excessive manure application reaching well above agronomic targets over the years may take several decades to meet environmental targets [74].

The tested soil P content was closely related to the P budgets in the Typic Hapludalf under study. The $\mathrm{P}$ requirement was $300 \mathrm{~kg} \mathrm{P} \mathrm{ha}^{-1}$ to maintain the soil $\mathrm{P}$ content close to $20 \mathrm{mg} \mathrm{P} \mathrm{dm}^{-3}$ over the experimental period; hence, approximately $27 \mathrm{~kg} \mathrm{P} \mathrm{ha}^{-1} \mathrm{yr}^{-1}$. This type of soil is effective at P-fixing due to its elevated sesquioxide content [75], but the soil's P-fixing capacity may vary widely between soils [76]. In comparison, soil with an 
initial P content of $7 \mathrm{mg} \mathrm{P} \mathrm{dm}^{-3}$ required $128 \mathrm{~kg} \mathrm{P} \mathrm{ha}^{-1}$ to reach the maintenance level of $20 \mathrm{mg} \mathrm{P} \mathrm{dm}^{-3}$ in an Inceptisol of Santa Catarina, Southern Brazil [77].

The relationship between the tested soil $\mathrm{K}$ content and the $\mathrm{K}$ budget depends largely on clay mineralogy, because illite-mica minerals can release forms of $\mathrm{K}$ that are not readily extractable by the routine soil $\mathrm{K}$ test method [30]. In contrast, there was a close relationship between the tested soil $\mathrm{K}$ and the $\mathrm{K}$ budget for the Typic Hapludalf that contained kaolinite clay [75]. Hence, only exchangeable $\mathrm{K}$ was reflected by the tested soil $\mathrm{K}$ of the Typic Hapludalf under study. The tested soil $\mathrm{Ca}$ and $\mathrm{Mg}$ were less related to the $\mathrm{Ca}$ and $\mathrm{Mg}$ budgets, likely indicating $\mathrm{Ca}$ and $\mathrm{Mg}$ leaching.

At the end of the 11 years of experimentation, the soil $\mathrm{Cu}$ increased up to $30 \mathrm{mg} \mathrm{Cu} \mathrm{kg}^{-1}$ and the $\mathrm{Zn}$ levels reached up to $35 \mathrm{mg} \mathrm{kg}^{-1}$ in the 0-10 $\mathrm{cm}$ layer, compared to $2 \mathrm{mg} \mathrm{Cu} \mathrm{kg}^{-1}$ and $3 \mathrm{mg} \mathrm{Zn} \mathrm{kg}^{-1}$ in the 10-20 cm layer. In a no-till Typic Hapludalf soil in Southern Brazil initially containing $4 \mathrm{mg}$ Cu-EDTA kg ${ }^{-1}$ and $4-10 \mathrm{mg} \mathrm{Zn-EDTA} \mathrm{kg}^{-1}$ in the $0-10 \mathrm{~cm}$ layer, repeated applications of $180 \mathrm{~kg} \mathrm{~N} \mathrm{ha}^{-1} \mathrm{yr}^{-1}$ of pig deep litter and pig slurry to a crop sequence of Zea mays and Avena strigosa over eight consecutive years increased the soil $\mathrm{Cu}$ and $\mathrm{Zn}$ in the surface soil layer and as deep as $15 \mathrm{~cm}$ at the highest dose [78]. The soil $\mathrm{Cu}$ in the upper 0-10 $\mathrm{cm}$ layer reached 11-29 $\mathrm{mg} \mathrm{Cu}$-EDTA kg${ }^{-1}$ with pig slurry and 50-122 mg Cu-EDTA kg ${ }^{-1}$ with pig deep litter. The soil $\mathrm{Zn}$ reached

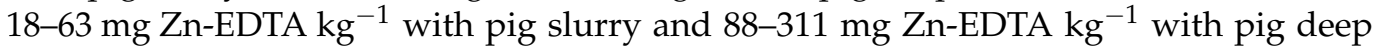
litter. Copper accumulated mainly in organic form, while zinc reacted preferentially with clay minerals.

In the experimental Typic Hapludalf soil, the initial soil $\mathrm{Cu}$ and $\mathrm{Zn}$ were not measured, but records of the 2009 analysis indicated values lower than $1 \mathrm{mg} \mathrm{kg}^{-1}$ for both micronutrients in the zero-fertilizer and mineral fertilizer treatments wherein no $\mathrm{Cu}$ or $\mathrm{Zn}$ were added. The soil $\mathrm{Cu}$ and $\mathrm{Zn}$ were thus much lower than in the study of Tiecher et al. [78] and reached lower values at the end of the experimental period. The ageing of the added $\mathrm{Cu}$, the organic matter content, the soil $\mathrm{pH}$, the soil texture, and the soil $\mathrm{P}$ impact soil $\mathrm{Cu}$ availability in the long term [79-81]. Because Typic Hapludalf soil has a limited capacity to fix $\mathrm{Cu}$ and $\mathrm{Zn}$, the sustainability of $\mathrm{N}$-based manure fertilization regimes is questionable.

\subsection{Nutrient-Use Efficiency}

The nutrient-use efficiency of pig deep litter was high for $\mathrm{N}$, as indicated by the ANR (Equation (7)). The high $\mathrm{N}$ recovery with pig deep litter is attributable to organic $\mathrm{N}$ forms being gradually mineralized during the season [82-84]. The successive additions of residues showing high C:N ratios and relatively low mineral $\mathrm{N}$ content, such as pig deep litter, increased the $\mathrm{N}$ availability over time [85], contributed to organic $\mathrm{N}$ accumulation, and likely improved the synchrony between the mineralization of organic $\mathrm{N}$ and the crop $\mathrm{N}$ demand. Organic fertilizers with a high ammoniacal $\mathrm{N}$ content applied before implanting the crops can result in the reduction of $\mathrm{N}$ losses, especially by leaching after absorption by clay minerals [86]. Shah et al. [87] found higher rates of organic $\mathrm{N}$ mineralization and nutrient-use efficiency in soils with $20 \%$ clay content.

The N-use efficiency was low with the application of pig slurry and cattle slurry. The application of organic fertilizers with high levels of ammoniacal $\mathrm{N}$ (e.g., pig slurry and cattle slurry) may lead to significant losses of $\mathrm{NH}_{3}$ by volatilization depending on the environmental conditions, the physical and chemical characteristics of the fertilizer, and the application mode $[82,88]$. Surface-applied organic fertilizers generally result in greater $\mathrm{N}$ losses compared to soil incorporation [82].

The low ANR for P compared to N (Table 4) may be explained in part by the low $\mathrm{P}$ requirements of the crop [89]. The low $\mathrm{P}$ recovery rates of 23,21 , and $18 \%$ at pig slurry application rates of 20,40 , and $80 \mathrm{~m}^{3} \mathrm{ha}^{-1}$, respectively, is attributable to the high binding energy required for the reaction between phosphate ions and the reactive soil mineral fractions [90]. The carboxylic and phenolic functional groups in organic matter can reduce $\mathrm{P}$ sorption by tackling positively charged sites on $\mathrm{Fe}$ and $\mathrm{Al}$ oxides [91,92]. As a result, increasing the soil organic matter through the application of organic fertilizers is a 
viable option to make phosphate fertilization more efficient, especially for small farmers who have difficulties acquiring costly mineral fertilizers. However, the imbalanced N:P ratio of manures makes such an option feasible only as long as the soil $\mathrm{P}$ does not reach environmentally critical values [92].

The high ANR for the cationic micronutrients raised the question of balancing crop biofortification with critical soil micronutrient test levels and soil contamination. Excessive $\mathrm{Cu}$ accumulation decreases soil biological quality by tackling soil respiration and catalytic functions [93,94]. Parent and Quinche [95] suggested a maximum soil Cu level of 6-8 mg $\mathrm{Cu}_{\text {Mehlich3 }} \mathrm{kg}^{-1}$ and soil $\mathrm{Zn}$ level of 11-17 $\mathrm{mg} \mathrm{Zn}_{\text {Mehlich3 }} \mathrm{kg}^{-1}$ for potato (Solanum tuberosum) and crucifers grown as vegetables. Although $\mathrm{Zn}$ can be supplied in large amounts without apparent toxic effects [96,97], Zn toxicity may occur and could be mitigated by heavy liming. Despite no Mn additions, Mn availability increased due to urea that acidified the soil [98] and maintained a soil pH below $4.8[99,100]$. The organic fertilizers applied in this study contained $\mathrm{Mn}$, but maintained a soil $\mathrm{pH}$ at higher levels, impacting the Mn availability.

\subsection{Setting Targets}

The application of different organic sources significantly increased the levels of macronutrients and micronutrients in the $0-10 \mathrm{~cm}$ layer (Figures 3 and 4 ). These increases in soil nutrient content due to the successive application of these animal residues bring several benefits to crop development $[101,102]$. Therefore, according to the interpretation tables proposed by the Soil Chemistry and Fertility Commission of the States of Rio Grande do Sul and Santa Catarina (27), the levels of P, K, Cu, Zn, and Mn in the soil when pig deep litter was applied at a depth of up to $10 \mathrm{~cm}$ are above the limits considered ideal for the good development of annual crops.

This demonstrates that successive applications of manure-sometimes in quantities greater than the needs of the crops-result in the accumulation of the nutrient on the soil surface. The transfer of this $\mathrm{P}$ accumulated in the soil surface layers by runoff to surrounding water bodies can cause the eutrophication and environmental deterioration of aquatic systems worldwide $[103,104]$. Thus, the transfer of P by runoff has been the object of study in traditional swine- and livestock-breeding countries around the world, including Brazil.

Successive manure applications lead to increases in $\mathrm{Cu}$ and $\mathrm{Zn}$ forms in soils under NTS, along with increases in their soluble and exchangeable forms $[78,105]$. This may increase the potential toxicity of these elements to plants [24,106] and enhance the transfer of $\mathrm{Cu}$ and $\mathrm{Zn}$ to surface water by surface runoff [24]. However, the increased concentrations of these heavy metals in surface water pose a serious environmental threat to living organisms and aquatic ecosystems, due to their nonbiodegradability, bioaccumulation, environmental stability, persistence, and biotoxic characteristics [107-109].

\subsection{Biofortification vs. Contamination}

The biofortification of human food, especially with Zn and Fe, is becoming an important issue in grain and vegetable production [110]. The objective of biofortification is to find ways to produce edible plants fortified with micronutrients that are easily assimilable by humans [111,112]. Research has shown that some crucifers [113], potato cultivars [114], onion cultivars [115], maize [116], and vegetable greens [117,118] could be biofortified with Zn or Fe. Manure applications could thus contribute to biofortification. However, plant contamination through the inappropriate use of $\mathrm{Cu}$ - or $\mathrm{Zn}$-based fertilizers and pesticides represents a risk for human health [119-121].

\section{Conclusions}

In this paper, we investigated the long-term effects of N-based organic and mineral fertilization on crop yield and nutrient budgets. For N-based fertilizer additions, all soil test levels, except those for Mg and Mn, increased systematically with the elemental budgets. The soil $\mathrm{pH}$ decreased with the mineral fertilization and increased as a result of organic 
fertilization. The apparent nutrient recovery rates were higher for $\mathrm{N}$-based organic $\mathrm{N}$ fertilization than for mineral fertilization due to the micronutrient supply, higher soil $\mathrm{pH}$, and/or improved synchrony between the soil $\mathrm{N}$ supply and the plant $\mathrm{N}$ demand.

As expected, the crop yields depended primarily on the fertilizer source and rate. Pig deep litter supplied more nutrients than any other nutrient source and could sustain crop production until the accumulation of phosphorus and micronutrients reached excessive amounts. The grain yield and oat aboveground biomass were higher under the organic than the mineral fertilization regimes, indicating a nutrient shortage with the mineral fertilization. As a result, the nutrient-use efficiency was higher under the organic than the mineral fertilization regime.

The soil micronutrient test levels generally increased when the nutrient additions exceeded the nutrient offtakes, posing a potential threat to the system's sustainability, especially regarding the soil $\mathrm{P}$ and $\mathrm{Cu}$ content. Nevertheless, the biofortification of crops via organic fertilizers could be a beneficial practice as long as environmental thresholds are not exceeded and the soils and crops are not contaminated. This long-term experiment conducted on a low-fertility Hapludalf soil showed that N-based manure additions could be appropriate for a decade or so but are unsustainable in the long run and difficult to recover from. The drawbacks of N-based applications could be overcome by the partial or complete replacement of organic fertilization by mineral fertilization, P-based and/or $\mathrm{Cu}$-based manure fertilization, or mixing and diluting composted manures with suitable mineral materials.

Supplementary Materials: The following are available online at https:/ / www.mdpi.com/article/10 .3390/agronomy12020243/s1, Figure S1: Change in climatic across seasons between winter 2009(\#1) and winter 2020 (\#23). Winter and summer periods extend from May through September and from October to April, respectively., Table S1: Total elements (mean \pm standard deviation) supplied by the fertilization regime.

Author Contributions: Conceptualization, P.A.A.F. and L.-É.P.; methodology, C.R.L., L.D.C., C.M., E.G., T.L.T. and N.M.P.; validation, P.A.A.F., C.A.C. and L.-É.P.; formal analysis, T.L.T., N.M.P. and L.D.C.; investigation, L.-É.P., G.B., P.A.A.F. and C.A.C.; resources, C.R.L., G.B. and C.A.C.; data curation, P.A.A.F., L.-É.P. and G.B.; writing—original draft preparation, P.A.A.F., L.-É.P. and G.B.; writing-review and editing, E.G., C.A.C. and C.R.L.; supervision, P.A.A.F.; project administration, P.A.A.F.; funding acquisition, G.B., C.A.C. and P.A.A.F. All authors have read and agreed to the published version of the manuscript.

Funding: This research was funded by Foundation for Research Support of the State of Rio Grande do Sul (FAPERGS) (process number 1971-2551/13-2) and the Brazilian National Council for Scientific and Technological Development (CNPq), process number 400982/2016-1.

Acknowledgments: We are grateful to the Foundation for Research Support of the State of Rio Grande do Sul (FAPERGS) and the Brazilian National Council for Scientific and Technological Development (CNPq), for scholarships and funding available for this study.

Conflicts of Interest: The authors declare that they have no conflict of interest.

\section{References}

1. Hollins, O.; Lee, P.; Sims, E.; Bertham, O.; Symington, H.; Bell, N.; Pfaltzgraff, L.; Sjogren, P. Towards a Circular Economy-Waste Management in the EU STUDY Science and Technology Options Assessment; European Union: Brussels, Belgium, 2017.

2. European Commission. A Sustainable Bioeconomy for Europe: Strengthening the Connection between Economy, Society and the Environment; European Commission: Brussels, Belgium, 2018; 107p. [CrossRef]

3. EUR-Lex Communication from the Commission to the European Parliament, the Council, the European Economic and Social Committee and the Committee of the Regions. Closing the Loop-An EU Action Plan for the Circular Economy. 2015. Available online: https:/ / eur-lex.europa.eu/legal-content/EN/TXT/?uri=CELEX\%3A52015DC0614 (accessed on 7 December 2021).

4. Chenu, C.; Angers, D.A.; Barré, P.; Derrien, D.; Arrouays, D.; Balesdent, J. Increasing Organic Stocks in Agricultural Soils: Knowledge Gaps and Potential Innovations. Soil Tillage Res. 2019, 188, 41-52. [CrossRef]

5. Messiga, A.J.; Ziadi, N.; Morel, C.; Grant, C.; Tremblay, G.; Lamarre, G.; Parent, L.E. Long Term Impact of Tillage Practices and Biennial P and N Fertilization on Maize and Soybean Yields and Soil P Status. Field Crops Res. 2012, 133, 10-22. [CrossRef] 
6. Ozlu, E.; Sandhu, S.S.; Kumar, S.; Arriaga, F.J. Soil Health Indicators Impacted by Long-Term Cattle Manure and Inorganic Fertilizer Application in a Corn-Soybean Rotation of South Dakota. Sci. Rep. 2019, 9, 11776. [CrossRef]

7. Zhang, Y.; Zhang, T.; Wang, Y.; Tan, C.; Zhang, L.; He, X.; Welacky, T.; Che, X.; Tang, X.; Wang, Z. Crop Production and Phosphorus Legacy with Long-Term Phosphorus- and Nitrogen-Based Swine Manure Applications under Corn-Soybean Rotation. Agronomy 2021, 11, 1548. [CrossRef]

8. Royer, I.; Simard, R.R.; Barnett, G.M.; Cluis, D.; Angers, D.A. Long-Term Effects of Liquid Hog Manure on the Phosphorus Status of a Silt Loam Cropped to Corn. Can. J. Soil Sci. 2003, 83, 589-600. [CrossRef]

9. He, M.; Xiong, X.; Wang, L.; Hou, D.; Bolan, N.S.; Ok, Y.S.; Rinklebe, J.; Tsang, D.C.W. A Critical Review on Performance Indicators for Evaluating Soil Biota and Soil Health of Biochar-Amended Soils. J. Hazard. Mater. 2021, 414, 125378. [CrossRef] [PubMed]

10. Khan, N.; Chowdhary, P.; Gnansounou, E.; Chaturvedi, P. Biochar and Environmental Sustainability: Emerging Trends and Techno-Economic Perspectives. Bioresour. Technol. 2021, 332, 125102. [CrossRef]

11. Dhaliwal, S.S.; Naresh, R.K.; Mandal, A.; Singh, R.; Dhaliwal, M.K. Dynamics and Transformations of Micronutrients in Agricultural Soils as Influenced by Organic Matter Build-up: A Review. Environ. Sustain. Indic. 2019, 1, 100007. [CrossRef]

12. Duffková, R.; Hejcman, M.; Libichová, H. Effect of Cattle Slurry on Soil and Herbage Chemical Properties, Yield, Nutrient Balance and Plant Species Composition of Moderately Dry Arrhenatherion Grassland. Agric. Ecosyst. Environ. 2015, 213, 281-289. [CrossRef]

13. Lourenzi, C.R.; Scherer, E.E.; Ceretta, C.A.; Tiecher, T.L.; Cancian, A.; Ferreira, P.A.A.; Brunetto, G. Atributos Químicos de Latossolo Após Sucessivas Aplicações de Composto Orgânico de Dejeto Líquido de Suínos. Pesqui. Agropecu. Bras. 2016, 51, 233-242. [CrossRef]

14. Perramon, B.; Bosch-Serra, A.D.; Domingo, F.; Boixadera, J. Organic and Mineral Fertilization Management Improvements to a Double-Annual Cropping System under Humid Mediterranean Conditions. Eur. J. Agron. 2016, 76, 28-40. [CrossRef]

15. Baligar, V.C.; Fageria, N.K.; He, Z.L. Nutrient use efficiency in plants. Commun. Soil Sci. Plant Anal. 2007, 32, 921-950. [CrossRef]

16. Ye, L.; Zhao, X.; Bao, E.; Li, J.; Zou, Z.; Cao, K. Bio-Organic Fertilizer with Reduced Rates of Chemical Fertilization Improves Soil Fertility and Enhances Tomato Yield and Quality. Sci. Rep. 2020, 10, 177. [CrossRef]

17. Doneda, A.; Aita, C.; Giacomini, S.J.; Miola, E.C.C.; Giacomini, D.A.; Schirmann, J.; Gonzatto, R. Fitomassa e Decomposição de Resíduos de Plantas de Cobertura Puras e Consorciadas. Rev. Bras. Ciência Solo 2012, 36, 1714-1723. [CrossRef]

18. Associação Brasileira de Proteína Animal. Relatório Annual; Associação Brasileira de Proteína Animal: São Paulo, Brazil, 2020.

19. Instituto Brasileiro de Geografia e Estatística. Pesquisa Trimestral Do Leite; Primeiros Resultados Dados Da Quantidade de Leite Cru Processado Pela Indústria; Instituto Brasileiro de Geografia e Estatística: São Paulo, Brazil, 2019.

20. Couto, R.D.R.; Ferreira, P.A.A.; Ceretta, C.A.; Lourenzi, C.R.; Facco, D.B.; Tassinari, A.; Piccin, R.; de Conti, L.; Gatiboni, L.C.; Schapanski, D.; et al. Phosphorus Fractions in Soil with a Long History of Organic Waste and Mineral Fertilizer Addition. Bragantia 2017, 76, 155-166. [CrossRef]

21. Lourenzi, C.R.; Ceretta, C.A.; Ciancio, N.H.R.; Tiecher, T.L.; da Silva, L.O.S.; de Conti, L.; Girotto, E.; Ferreira, P.A.A.; Vidal, R.F.; Scopel, G.; et al. Forms of Nitrogen and Phosphorus Transfer by Runoff in Soil under No-Tillage with Successive Organic Waste and Mineral Fertilizers Applications. Agric. Water Manag. 2021, 248, 106779. [CrossRef]

22. Adeli, A.; Varco, J.J.; Rowe, D.E. Swine Effluent Irrigation Rate and Timing Effects on Bermudagrass Growth, Nitrogen and Phosphorus Utilization, and Residual Soil Nitrogen. J. Environ. Qual. 2003, 32, 681-686. [CrossRef] [PubMed]

23. Gatiboni, L.C.; Brunetto, G.; Kaminski, J.; Rheinheimer, D.D.S.; Ceretta, C.A.; Basso, C.J. Formas de Fósforo No Solo Após Sucessivas Adições de Dejeto Líquido de Suínos Em Pastagem Natural. Rev. Bras. Ciência Solo 2008, 32, 1753-1761. [CrossRef]

24. Girotto, E.; Ceretta, C.A.; Lourenzi, C.R.; Lorensini, F.; Tiecher, T.L.; Vieira, R.C.B.; Trentin, G.; Basso, C.J.; Miotto, A.; Brunetto, G. Nutrient Transfers by Leaching in a No-Tillage System through Soil Treated with Repeated Pig Slurry Applications. Nutr. Cycl. Agroecosyst. 2013, 95, 115-131. [CrossRef]

25. Wang, W.; Liang, T.; Wang, L.; Liu, Y.; Wang, Y.; Zhang, C. The Effects of Fertilizer Applications on Runoff Loss of Phosphorus. Environ. Earth Sci. 2013, 68, 1313-1319. [CrossRef]

26. Myint, A.K.; Yamakawa, T.; Kajihara, Y.; Zenmyo, T. Application of Different Organic and Mineral Fertilizers on the Growth, Yield and Nutrient Accumulation of Rice in a Japanese Ordinary Paddy Field. Sci. World J. 2010, 5, 48-54. [CrossRef]

27. Seidel, E.P.; Gonçalves, A.C., Jr.; Vanin, J.P.; Strey, L.; Schwantes, D.; Nacke, H. Aplicacao de Dejetos de Suinos Na Cultura Do Milho Cultivado Em Sistema de Plantio Direto. Acta Sci. Technol. 2010, 32, 113-118.

28. Guo, T.; Lou, C.; Zhai, W.; Tang, X.; Hashmi, M.Z.; Murtaza, R.; Li, Y.; Liu, X.; Xu, J. Increased Occurrence of Heavy Metals, Antibiotics and Resistance Genes in Surface Soil after Long-Term Application of Manure. Sci. Total Environ. 2018, 635, 995-1003. [CrossRef]

29. Motew, M.; Chen, X.; Booth, E.G.; Carpenter, S.R.; Pinkas, P.; Zipper, S.C.; Loheide, S.P.; Donner, S.D.; Tsuruta, K.; Vadas, P.A.; et al. The Influence of Legacy P on Lake Water Quality in a Midwestern Agricultural Watershed. Ecosystems 2017, 20, 1468-1482. [CrossRef]

30. Damar, H.; Ziadi, N.; Lafond, J.; Parent, L.E. Potassium Transformation in Clay Soil with Contrasting K Budgets in Long-Term Experiment. Agron. J. 2020, 112, 5180-5192. [CrossRef]

31. Damar, H.; Ziadi, N.; Lafond, J.; Parent, L.E. Long-Term Impact of Fertilizer Sources on Cyclic P Budget and Soil P Status under Ley Farming System. Nutr. Cycl. Agroecosyst. 2021, 119, 165-180. [CrossRef] 
32. Damar, H.; Ziadi, N.; Lafond, J.; Pageau, D.; Lajeunesse, J.; Parent, L.E. Cyclic Yield Stability of Ley Farming System in Northern Quebec. Agron. J. 2019, 111, 3310-3319. [CrossRef]

33. Messiga, A.J.; Ziadi, N.; Angers, D.A.; Morel, C.; Parent, L.E. Tillage Practices of a Clay Loam Soil Affect Soil Aggregation and Associated $C$ and P Concentrations. Geoderma 2011, 164, 225-231. [CrossRef]

34. Parent, L.E.; Jamaly, R.; Atucha, A.; JeanneParent, E.; Workmaster, B.A.; Ziadi, N.; Parent, S.É. Current and Next-Year Cranberry Yields Predicted from Local Features and Carryover Effects. PLoS ONE 2021, 16, e0250575. [CrossRef] [PubMed]

35. Soil Survey Staff Keys to Soil Taxonomy. Soil Conserv. Serv. 2014, 12, 410.

36. Comissao de Química e Fertilidade do Solo Rio Grande do Sul e Santa Catarina CQFS RS/SC. Manual de Adubação e de Calagem Para os Estados Do Rio Grande so Sul e Santa Catarina, 11th ed.; Sociedade Brasileira de Ciencia do Solo/Núcleo Regional Sul: Porto Alegre, Brazil, 2016; ISBN 978-85-66301-80-9.

37. Tedesco, M.; Gianello, C.; Bissani, C. Análises de Solo, Plantas e Outros Materiais; Universidade Federal do Rio Grande do Sul: Porto Alegre, Brazil, 1995; Volume 5.

38. Murphy, J.; Riley, J.P. A Modified Single Solution Method for the Determination of Phosphate in Natural Waters. Anal. Chim. Acta 1962, 27, 31-36. [CrossRef]

39. Kaminski, J.; Gatiboni, L.C.; Rheinheimer, D.S.; Martins, J.R.; Santos, E.J.S.; Tissot, C.A. Estimativa Da Acidez Potencial Em Solos e Sua Implicação No Cálculo Da Necessidade de Calcário. Rev. Bras. Ciência Solo 2002, 26, 1107-1113. [CrossRef]

40. Lourenzi, C.R.; Ceretta, C.A.; Cerini, J.B.; Ferreira, P.A.A.; Lorensini, F.; Girotto, E.; Tiecher, T.L.; Schapanski, D.E.; Brunetto, G. Available Content, Surface Runoff and Leaching of Phosphorus Forms in a Typic Hapludalf Treated with Organic and Mineral Nutrient Sources. Rev. Bras. Ciência Solo 2014, 38, 544-556. [CrossRef]

41. Empresa Brasileira de Pesquisa Agropecuária. Manual de Metodos de Análise de Solo; Embrapa: Brasília, Brazil, 1997; ISBN 8585864036.

42. Ma, S.; He, F.; Tian, D.; Zou, D.; Yan, Z.; Yang, Y.; Zhou, T.; Huang, K.; Shen, H.; Fang, J. Variations and Determinants of Carbon Content in Plants: A Global Synthesis. Biogeosciences 2018, 15, 693-702. [CrossRef]

43. Tremblay, N.; Bouroubi, Y.M.; Bélec, C.; Mullen, R.W.; Kitchen, N.R.; Thomason, W.E.; Ebelhar, S.; Mengel, D.B.; Raun, W.R.; Francis, D.D.; et al. Corn Response to Nitrogen Is Influenced by Soil Texture and Weather. Agron. J. 2012, 104, $1658-1671$. [CrossRef]

44. Filzmoser, P.; Hron, K.; Reimann, C. Univariate Statistical Analysis of Environmental (Compositional) Data: Problems and Possibilities. Sci. Total Environ. 2009, 407, 6100-6108. [CrossRef]

45. De Wit, C.T. Resource Use Efficiency in Agriculture. Agric. Syst. 1992, 40, 125-151. [CrossRef]

46. Gougoulias, C.; Clark, J.M.; Shaw, L.J. The Role of Soil Microbes in the Global Carbon Cycle: Tracking the below-Ground Microbial Processing of Plant-Derived Carbon for Manipulating Carbon Dynamics in Agricultural Systems. J. Sci. Food Agric. 2014, 94, 2362-2371. [CrossRef] [PubMed]

47. Bailey, V.L.; Pries, C.H.; Lajtha, K. What Do We Know about Soil Carbon Destabilization? Environ. Res. Lett. 2019, $14,083004$. [CrossRef]

48. Li, J.; Wen, Y.; Li, X.; Li, Y.; Yang, X.; Lin, Z.; Song, Z.; Cooper, J.M.; Zhao, B. Soil Labile Organic Carbon Fractions and Soil Organic Carbon Stocks as Affected by Long-Term Organic and Mineral Fertilization Regimes in the North China Plain. Soil Tillage Res. 2018, 175, 281-290. [CrossRef]

49. Walia, M.K.; Dick, W.A. Selected Soil Physical Properties and Aggregate-Associated Carbon and Nitrogen as Influenced by Gypsum, Crop Residue, and Glucose. Geoderma 2018, 320, 67-73. [CrossRef]

50. Couto, R.; Faversani, J.; Ceretta, C.A.; Ferreira, P.A.A.; Marchezan, C.; Facco, D.B.; Garlet, L.P.; Silva, J.S.; Comin, J.J.; Bizzi, C.A.; et al. Health Risk Assessment and Soil and Plant Heavy Metal and Bromine Contents in Fi Eld Plots after Ten Years of Organic and Mineral Fertilization. Ecotoxicol. Environ. Saf. 2018, 153, 142-150. [CrossRef] [PubMed]

51. Ning, C.C.; Gao, P.D.; Wang, B.Q.; Lin, W.P.; Jiang, N.H.; Cai, K.Z. Impacts of Chemical Fertilizer Reduction and Organic Amendments Supplementation on Soil Nutrient, Enzyme Activity and Heavy Metal Content. J. Integr. Agric. 2017, 16, 1819-1831. [CrossRef]

52. Crusciol, C.A.C.; de Campos, M.; Martello, J.M.; Alves, C.J.; Nascimento, C.A.C.; dos Reis Pereira, J.C.; Cantarella, H. Organomineral Fertilizer as Source of P and K for Sugarcane. Sci. Rep. 2020, 10, 53398. [CrossRef]

53. Kominko, H.; Gorazda, K.; Wzorek, Z. Formulation and Evaluation of Organo-Mineral Fertilizers Based on Sewage Sludge Optimized for Maize and Sunflower Crops. Waste Manag. 2021, 136, 57-66. [CrossRef]

54. Mazeika, R.; Staugaitis, G.; Baltrusaitis, J. Engineered Pelletized Organo-Mineral Fertilizers (OMF) from Poultry Manure, Diammonium Phosphate and Potassium Chloride. ACS Sustain. Chem. Eng. 2016, 4, 2279-2285. [CrossRef]

55. Merisier, M.J.; Khiari, L.; Parent, L.E.; Karam, A. Organo-Mineral Phosphate Fertilizer as Alternative to Di-Ammonium Phosphate in Potato Production. In Proceedings of the III Symposium on Agricultural and Agroindustrial Waste Management, Sao Pedro, Brazil, 12-14 March 2013

56. Zebarth, B.J.; Chabot, R.; Coulombe, J.; Simard, R.R.; Douheret, J.; Tremblay, N. Pelletized Organo-Mineral Fertilizer Product as a Nitrogen Source for Potato Production. Can. J. Soil Sci. 2005, 85, 387-395. [CrossRef]

57. Albuquerque, J.A.; Reinert, D.J. Soil and Plant Variability in a Typic Hapludalf. Rev. Bras. Cienc. Solo 1996, 20, 151-157.

58. Lal, R. Soil Health and Carbon Management. Food Energy Secur. 2016, 5, 212-222. [CrossRef] 
59. Bhardwaj, A.K.; Rajwar, D.; Mandal, U.K.; Ahamad, S.; Kaphaliya, B.; Minhas, P.S.; Prabhakar, M.; Banyal, R.; Singh, R.; Chaudhari, S.K.; et al. Impact of Carbon Inputs on Soil Carbon Fractionation, Sequestration and Biological Responses under Major Nutrient Management Practices for Rice-Wheat Cropping Systems. Sci. Rep. 2019, 9, 9114. [CrossRef]

60. Chen, A.; Xie, X.; Dorodnikov, M.; Wang, W.; Ge, T.; Shibistova, O.; Wei, W.; Guggenberger, G. Response of Paddy Soil Organic Carbon Accumulation to Changes in Long-Term Yield-Driven Carbon Inputs in Subtropical China. Agric. Ecosyst. Environ. 2016, 232, 302-311. [CrossRef]

61. Liu, Y.; Ge, T.; Zhu, Z.; Liu, S.; Luo, Y.; Li, Y.; Wang, P.; Gavrichkova, O.; Xu, X.; Wang, J.; et al. Carbon Input and Allocation by Rice into Paddy Soils: A Review. Soil Biol. Biochem. 2019, 133, 97-107. [CrossRef]

62. Lourenzi, C.R.; Ceretta, C.A.; Silva, S.; Trentin, G.; Girotto, E. Soil Chemical Properties Related to Acidity under Successive Pig Slurry Applications. Rev. Bras. Cienc. Solo 2011, 35, 1827-1836. [CrossRef]

63. Fageria, N.K.; Filho, M.P.B.; Moreira, A.; Guimarães, C.M. Foliar Fertilization of Crop Plants. J. Plant Nutr. 2009, $32,1044-1064$. [CrossRef]

64. Kochian, L.V.; Piñeros, M.A.; Liu, J.; Magalhaes, J.V. Plant Adaptation to Acid Soils: The Molecular Basis for Crop Aluminum Resistance. Annu. Rev. Plant Biol. 2015, 66, 571-598. [CrossRef] [PubMed]

65. Mendes, L.A.; Avellan, A.; Cruz, N.C.; Palito, C.; Römkens, P.F.A.M.; Amorim, M.J.B.; Tarelho, L.A.C.; Rodrigues, S.M. Biomass Ash Formulations as Sustainable Improvers for Mining Soil Health Recovery: Linking Soil Properties and Ecotoxicity. Environ. Pollut. 2021, 291, 118165. [CrossRef]

66. Mowrer, J.; Endale, D.M.; Schomberg, H.H.; Norris, S.E.; Woodroof, R.H. Liming Potential of Poultry Litter in a Long-Term Tillage Comparison Study. Soil Tillage Res. 2020, 196, 104446. [CrossRef]

67. Khiari, L.; Karam, A.; Parent, L.E.; Gagné, G. Determination of Effective Calcium Carbonate Equivalence of Primary DeInking Paper Sludges. In Proceedings of the SIGERA III International Symposium on Agricultural and Agroindustrial Waste Management, Sao Pedro, Brazil, 14 March 2013.

68. Wang, N.; Xu, R.K.; Li, J.Y. Amelioration of an Acid Ultisol by Agricultural By-Products. Land Degrad. Dev. 2011, 22, 513-518. [CrossRef]

69. Culman, S.; Fulford, A.; Camberato, J.; Steinke, K. The College of Food, Agricultural, and Environmental Sciences; The Ohio State University: Columbus, OH, USA, 2020.

70. Guardini, R.; Comin, J.J.; Schmitt, D.E.; Tiecher, T.; Bender, M.A.; dos Santos, D.R.; Mezzari, C.P.; Oliveira, B.S.; Gatiboni, L.C.; Brunetto, G. Accumulation of Phosphorus Fractions in Typic Hapludalf Soil after Long-Term Application of Pig Slurry and Deep Pig Litter in a No-Tillage System. Nutr. Cycl. Agroecosyst. 2012, 93, 215-225. [CrossRef]

71. Ceretta, C.A.; Lorensini, F.; Brunetto, G.; Girotto, E.; Gatiboni, L.C.; Lourenzi, C.R.; Tiecher, T.L.; de Conti, L.; Trentin, G.; Miotto, A. Frações de Fósforo No Solo Após Sucessivas Aplicações de Dejetos de Suínos Em Plantio Direto. Pesqui. Agropecu. Bras. 2010, 45, 593-602. [CrossRef]

72. Lourenzi, C.R.; Ceretta, C.A.; da Silva, L.S.; Girotto, E.; Lorensini, F.; Tiecher, T.L.; de Conti, L.; Trentin, G.; Brunetto, G. Nutrients in Soil Layers under No-Tillage after Successive Pig Slurry Applications. Rev. Bras. Ciência Solo 2013, 37, 157-167. [CrossRef]

73. Ceretta, C.A.; Girotto, E.; Lourenzi, C.R.; Trentin, G.; Vieira, R.C.B.; Brunetto, G. Nutrient Transfer by Runoff under No Tillage in a Soil Treated with Successive Applications of Pig Slurry. Agric. Ecosyst. Environ. 2010, 139, 689-699. [CrossRef]

74. McDowell, R.; Dodd, R.; Pletnyakov, P.; Noble, A. The Ability to Reduce Soil Legacy Phosphorus at a Country Scale. Front. Environ. Sci. 2020, 8, 6. [CrossRef]

75. Fink, J.R.; Inda, A.V.; Bayer, C.; Torrent, J.; Barrón, V. Mineralogy and Phosphorus Adsorption in Soils of South and Central-West Brazil under Conventional and No-Tillage Systems. Acta Sci. Agron. 2014, 36, 379-387. [CrossRef]

76. Dos Santos, F.C.; Neves, J.C.L.; Novais, R.F.; Victor Hugo Alvarez, V.; Sediyama, C.S. Modelagem Da Recomendação de Corretivos e Fertilizantes Para a Cultura Da Soja. Rev. Bras. Ciência Solo 2008, 32, 1661-1674. [CrossRef]

77. Weingartner, S.; Gatiboni, L.C.; Dall'Orsoletta, D.J.; Kurtz, C.; Mussi, M. Rates and Localization of Phosphorus Fertilizer on Onion Yield. Rev. Ciências Agroveterinárias 2018, 17, 23-29. [CrossRef]

78. Tiecher, T.L.; Ceretta, C.A.; Comin, J.J.; Girotto, E.; Miotto, A.; de Moraes, M.P.; Benedet, L.; Ferreira, P.A.A.; Lorenzi, C.R.; Couto, R.D.R.; et al. Forms and Accumulation of Copper and Zinc in a Sandy Typic Hapludalf Soil after Long-Term Application of Pig Slurry and Deep Litter. Rev. Bras. Ciência Solo 2013, 37, 812-824. [CrossRef]

79. Moraghan, J.T.; Mascagni, H.J. Environmental and Soil Factors Affecting Micronutrient Deficiencies and Toxicities. Micronutr. Agric. 2018, 4, 371-425. [CrossRef]

80. Sims, J.T.; Johnson, G.V. Micronutrient Soil Tests. Micronutr. Agric. 2018, 4, 427-476. [CrossRef]

81. Zeng, S.; Li, J.; Wei, D.; Ma, Y. A New Model Integrating Short- and Long-Term Aging of Copper Added to Soils. PLoS ONE 2017, 12, e0182944. [CrossRef]

82. Giacomini, S.J.; Aita, C.; Pujol, S.B.; Miola, E.C.C. Transformações Do Nitrogênio No Solo Após Adição de Dejeto Líquido e Cama Sobreposta de Suínos. Pesqui. Agropecu. Bras. 2013, 48, 211-219. [CrossRef]

83. Hernández, D.; Polo, A.; Plaza, C. Long-Term Effects of Pig Slurry on Barley Yield and N Use Efficiency under Semiarid Mediterranean Conditions. Eur. J. Agron. 2013, 44, 78-86. [CrossRef]

84. Mallory, E.B.; Griffin, T.S. Impacts of Soil Amendment History on Nitrogen Availability from Manure and Fertilizer. Soil Sci. Soc. Am. J. 2007, 71, 964. [CrossRef] 
85. Gutser, R.; Ebertseder, T.; Weber, A.; Schraml, M.; Schmidhalter, U. Short-Term and Residual Availability of Nitrogen after Long-Term Application of Organic Fertilizers on Arable Land. J. Plant Nutr. Soil Sci. 2005, 168, 439-446. [CrossRef]

86. El-Shafey, O.I.; Fathy, N.A.; El-Nabarawy, T.A. Sorption of Ammonium Ions onto Natural and Modified Egyptian Kaolinites: Kinetic and Equilibrium Studies. Adv. Phys. Chem. 2014, 2014, 1-12. [CrossRef]

87. Shah, G.M.; Rashid, M.I.; Shah, G.A.; Groot, J.C.J.; Lantinga, E.A. Mineralization and Herbage Recovery of Animal Manure Nitrogen after Application to Various Soil Types. Plant Soil 2013, 365, 69-79. [CrossRef]

88. Port, O.; Aita, C.; Giacomini, S.J. Perda de Nitrogênio Por Volatilização de Amônia Com o Uso de Dejetos de Suínos Em Plantio Direto. Pesqui. Agropecu. Bras. 2003, 38, 857-865. [CrossRef]

89. Ceretta, C.A.; Durigon, R.; Basso, C.J.; Rocha Barcellos, L.A.; Beber Vieira, F.C. Características Químicas de Solo Sob Aplicação de Esterco Líquide de Suínos Em Pastagem Natural. Pesqui. Agropecu. Bras. 2003, 38, 729-735. [CrossRef]

90. Lourenzi, C.R.; Ceretta, C.A.; Brunetto, G.; Girotto, E.; Tiecher, T.L.; Vieira, R.C.B.; Cancian, A.; Ferreira, P.A.A. Pig Slurry and Nutrient Accumulation and Dry Matter and Grain Yield in Various Crops. Rev. Bras. Ciência Solo 2014, 38, 949-958. [CrossRef]

91. Hue, N.V. Effects of Organic Acids/Anions on P Sorption and Phytoavailability in Soils with Different Mineralogies. Soil Sci. 1991, 152, 463-471. [CrossRef]

92. Khiari, L.; Parent, L.E. Phosphorus Transformations in Acid Light-Textured Soils Treated with Dry Swine Manure. Can. J. Soil Sci. 2005, 85, 75-87. [CrossRef]

93. Klimek, B. Effect of Long-Term Zinc Pollution on Soil Microbial Community Resistance to Repeated Contamination. Bull. Environ. Contam. Toxicol. 2012, 88, 617-622. [CrossRef]

94. Mathur, S.P.; Macdougall, J.I.; McGrath, M. Levels of Activities of Some Carbohydrases, Protease, Lipase, and Phosphatase in Organic Soils of Differing Copper Content. Soil Sci. 1980, 129, 376-385. [CrossRef]

95. Parent, L.E.; Quinche, M. Micronutrient Soil and Tissue Test Interpretation for Vegetable Crops in Eastern Canada. J. Sci. Hortic. For. 2021, 3, 1-17.

96. Murphy, L.S.; Walsh, L.M. Correction of Micronutrient Deficiencies with Fertilizers. Micronutr. Agric. 1972, 129, $376-385$. [CrossRef]

97. White, P.J.; Broadley, M.R. Physiological Limits to Zinc Biofortification of Edible Crops. Front. Plant Sci. 2011, 2, 80. [CrossRef] [PubMed]

98. Boyer, J. Toxicité Apparente de Certains Engrais Phosphatés et Intoxication Manganique Induite; 1980. Available online: https://horizon.documentation.ird.fr/exl-doc/pleins_textes/cahiers/PTP/1428.PDF (accessed on 7 December 2021).

99. Ouellette, G.J.; Généreux, H. Influence Du Ph et Des Elements Fertilisants Sur l'intoxication Manganique de La Pomme de Terre. Can. J. Soil Sci. 2011, 45, 347-353. [CrossRef]

100. Ouellette, G.J.; Généreux, H. Influence de l'intoxication Manganique Sur Six Variétés de Pomme de Terre. Can. J. Soil Sci. 2011, 45, 24-32. [CrossRef]

101. Rayne, N.; Aula, L. Livestock Manure and the Impacts on Soil Health: A Review. Soil Syst. 2020, 4, 64. [CrossRef]

102. Wang, X.; Jia, Z.; Liang, L.; Yang, B.; Ding, R.; Nie, J.; Wang, J. Impacts of Manure Application on Soil Environment, Rainfall Use Efficiency and Crop Biomass under Dryland Farming. Sci. Rep. 2016, 6, 20994. [CrossRef]

103. Kim, J.S.; Oh, S.Y.; Oh, K.Y. Nutrient Runoff from a Korean Rice Paddy Watershed during Multiple Storm Events in the Growing Season. J. Hydrol. 2006, 327, 128-139. [CrossRef]

104. Yan, X.; Wei, Z.; Hong, Q.; Lu, Z.; Wu, J. Phosphorus Fractions and Sorption Characteristics in a Subtropical Paddy Soil as Influenced by Fertilizer Sources. Geoderma 2017, 295, 80-85. [CrossRef]

105. Girotto, E.; Ceretta, C.A.; Brunetto, G.; Andrade, J.G.D.; Zalamena, J. Formas de Perdas de Cobre e Fósforo Em Água de Escoamento Superficial e Percolação Em Solo Sob Aplicações Sucessivas de Dejeto Líquido de Suínos. Ciência Rural 2010, 40, 1948-1954. [CrossRef]

106. Tiecher, T.L.; Tiecher, T.; Ceretta, C.A.; Ferreira, P.A.A.; Nicoloso, F.T.; Soriani, H.H.; Tassinari, A.; Paranhos, J.T.; de Conti, L.; Brunetto, G. Physiological and Nutritional Status of Black Oat (Avena strigosa Schreb.) Grown in Soil with Interaction of High Doses of Copper and Zinc. Plant Physiol. Biochem. 2016, 106, 253-263. [CrossRef]

107. Khan, K.S.; Joergensen, R.G. Stoichiometry of the Soil Microbial Biomass in Response to Amendments with Varying C/N/P/S Ratios. Biol. Fertil. Soils 2019, 55, 265-274. [CrossRef]

108. Shaheen, N.; Ahmed, M.K.; Islam, M.S.; Habibullah-Al-Mamun, M.; Tukun, A.B.; Islam, S.; Abu, A.T. Health Risk Assessment of Trace Elements via Dietary Intake of "non-Piscine Protein Source" Foodstuffs (Meat, Milk and Egg) in Bangladesh. Environ. Sci. Pollut. Res. Int. 2016, 23, 7794-7806. [CrossRef]

109. Ustaoğlu, F.; Islam, M.S. Potential Toxic Elements in Sediment of Some Rivers at Giresun, Northeast Turkey: A Preliminary Assessment for Ecotoxicological Status and Health Risk. Ecol. Indic. 2020, 113, 106237. [CrossRef]

110. Brevik, E.C.; Sauer, T.J. The Past, Present, and Future of Soils and Human Health Studies. Soil 2015, 1, 35-46. [CrossRef]

111. Food and Agriculture Organization of the United Nations. Biofortification: Better Crops, Better Nutrition. Available online: https://www.fao.org/north-america/news/detail/en/c/1144424/ (accessed on 7 December 2021).

112. Clemens, S. How Metal Hyperaccumulating Plants Can Advance Zn Biofortification. Plant Soil 2017, 411, 111-120. [CrossRef]

113. Cartea, M.E.; Francisco, M.; Soengas, P.; Velasco, P. Phenolic Compounds in Brassica Vegetables. Molecules 2010, 16, 251-280. [CrossRef] 
114. Nassar, A.M.K.; Sabally, K.; Kubow, S.; Leclerc, Y.N.; Donnelly, D.J. Some Canadian-Grown Potato Cultivars Contribute to a Substantial Content of Essential Dietary Minerals. J. Agric. Food Chem. 2012, 60, 4688-4696. [CrossRef]

115. Petrovic, B.; Ekara, A.S.; Pokluda, R. Biofertilizers Enhance Quality of Onion. Agronomy 2020, 10, 1937. [CrossRef]

116. Mallikarjuna, M.G.; Thirunavukkarasu, N.; Sharma, R.; Shiriga, K.; Hossain, F.; Bhat, J.S.; Mithra, A.C.R.; Marla, S.S.; Manjaiah, K.M.; Rao, A.R.; et al. Comparative Transcriptome Analysis of Iron and Zinc Deficiency in Maize (Zea mays L.). Plants 2020, 9, 1812. [CrossRef]

117. Giordano, M.; El-Nakhel, C.; Pannico, A.; Kyriacou, M.C.; Stazi, S.R.; de Pascale, S.; Rouphael, Y. Iron Biofortification of Red and Green Pigmented Lettuce in Closed Soilless Cultivation Impacts Crop Performance and Modulates Mineral and Bioactive Composition. Agronomy 2019, 9, 290. [CrossRef]

118. Rugeles-Reyes, S.M.; Cecílio Filho, A.B.; López Aguilar, M.A.; Silva, P.H.S. Foliar Application of Zinc in the Agronomic Biofortification of Arugula. Food Sci. Technol. 2019, 39, 1011-1017. [CrossRef]

119. Agueh, V.; Degbey, C.C.; Sossa-Jerome, C.; Adomahou, D.; Paraiso, M.N.; Vissoh, S.; Makoutode, M.; Fayomi, B. Niveau de Contamination des Produits Maraîchers Par Les Substances Toxiques Sur Le Site de Houéyiho au Bénin. Int. J. Biol. Chem. Sci. 2015, 9, 542-551. [CrossRef]

120. Xiong, Z.T.; Wang, H. Copper Toxicity and Bioaccumulation in Chinese Cabbage (Brassica pekinensis Rupr.). Environ. Toxicol. 2005, 20, 188-194. [CrossRef]

121. Yang, J.; Ma, S.; Zhou, J.; Song, Y.; Li, F. Heavy Metal Contamination in Soils and Vegetables and Health Risk Assessment of Inhabitants in Daye, China. J. Int. Med. Res. 2018, 46, 3374-3387. [CrossRef] 